\title{
An Ethiopian-Headed Serpent in the Cantigas de Santa María: Sin, Sex, and Color in Late Medieval Castile
}

\author{
PAMELA A. PATTON Index of Christian Art, Princeton University
}

For Madeline H. Caviness

Cast thy bread upon the running waters:

for after a long time thou shalt find it again (Eccles. 11:1)

Abstract

An unconventional portrayal of the serpent of the Temptation in the Florence codex of the Cantigas de Santa María (Biblioteca nazionale centrale di Firenze, MS B.R. 20) manifests significant developments in the visual and epistemic norms of late medieval Castile. The satanic serpent's black face and stereotyped African features link to cultural traditions well beyond Iberia, most notably the topos of the "Ethiopian," which blended the actual and fantastical in deeply symbolic ways. Most crucial to the reading of the motif in the cantiga were the Ethiopian's longstanding associations with sin and diabolism, rooted in early monastic Christianity but preserved in later medieval monastic and romance literature as well as in visual images found in Iberian contexts. Yet the otherwise conventional femininity of the serpent's head must have connected still more specifically to medieval stereotypes of black women as hypersexual, distasteful, and dangerous. Iberian awareness of these stereotypes, attested by the caricatured black women of medieval Castilian exempla, poetry, and historical texts, surely facilitated recognition of the complementary binaries central to this cantiga, in that Satan's blackness and sensuality invert Eve's whiteness and erstwhile purity, foreshadowing her capitulation to the darkness of sin and sex as an antitype of the faultless Virgin. The innovative image thus reveals both its artist's sensitivity to broad European cultural trends and the resonance of skin color in a region where both color and race would soon become inescapably concrete concerns. monstrous hybrid confronts the young Eve in an illustrated thirteenth-century manuscript of the Cantigas de Santa María now in Florence (Biblioteca nazionale centrale di Firenze, MS B.R. 20). Twined clumsily around the Tree of Knowledge in the first and third panels of the unfinished illustration of Cantiga 320, the serpentine, winged body of Eve's interlocutor accords with many Gothic depictions of the devil in serpent's guise when he tempts Adam and Eve; so do its human head and feminine headdress (fol. 51r; Figs. 1-2). Here, however, the creature's conventionality ends, for the face that glances sidelong from beneath the stylish Castilian chaplet belongs not to the pale, idealized maiden of Gothic tradition but to her boldly inverted caricature: it is a dark, exaggerated visage with oversize eyes, broad scarlet lips, and a charcoal-black complexion.

Uncomfortably resonant with modern racial stereotypes, the black-faced serpent in this manuscript resists contextualization. While the scene's general iconography clearly derives from the cosmopolitan court milieu of the manuscript's patron, Alfonso X "the Wise" of Castile (r. 1252-84), the serpent's dark skin and cartoonlike features diverge radically from the iconographic traditions practiced both there and throughout medieval western Europe. The one other depiction of the Temptation of Adam and Eve in the Cantigas volumes, found in the illustration of Cantiga 60, portrays a serpent with a reptilian head (Madrid, Real Biblioteca del Monasterio de San Lorenzo de El Escorial [hereafter RBME], MS T-I-1, fol. 88v), ${ }^{1}$ and no similar black-faced figure appears elsewhere in the lavish output of Alfonso's highly active scriptorium or in the

The research and publication of this article were supported by the Meadows School of the Arts and the University Research Council of Southern Methodist University. I would like to thank the anonymous reviewers who read the manuscript for Gesta, as well as Alicia Zuese, Andrew Beresford, William Voelkle, Eric Marshall White, and the students in my 2014 seminar, “The Medieval Other," for their suggestions and critique. Thanks above all to my former student Alexandra Portaro, whose questions about this illustration first challenged me to think harder about it.

1. For this and a somewhat later reptilian example from the Castigos del Rey Don Sancho, see Ana Domínguez Rodríguez and Pilar Treviño Gajardo, Las Cantigas de Santa María: formas e imágenes (Madrid: AyN Ediciones, 2007), 169-70, esp. figs. 124-25. 


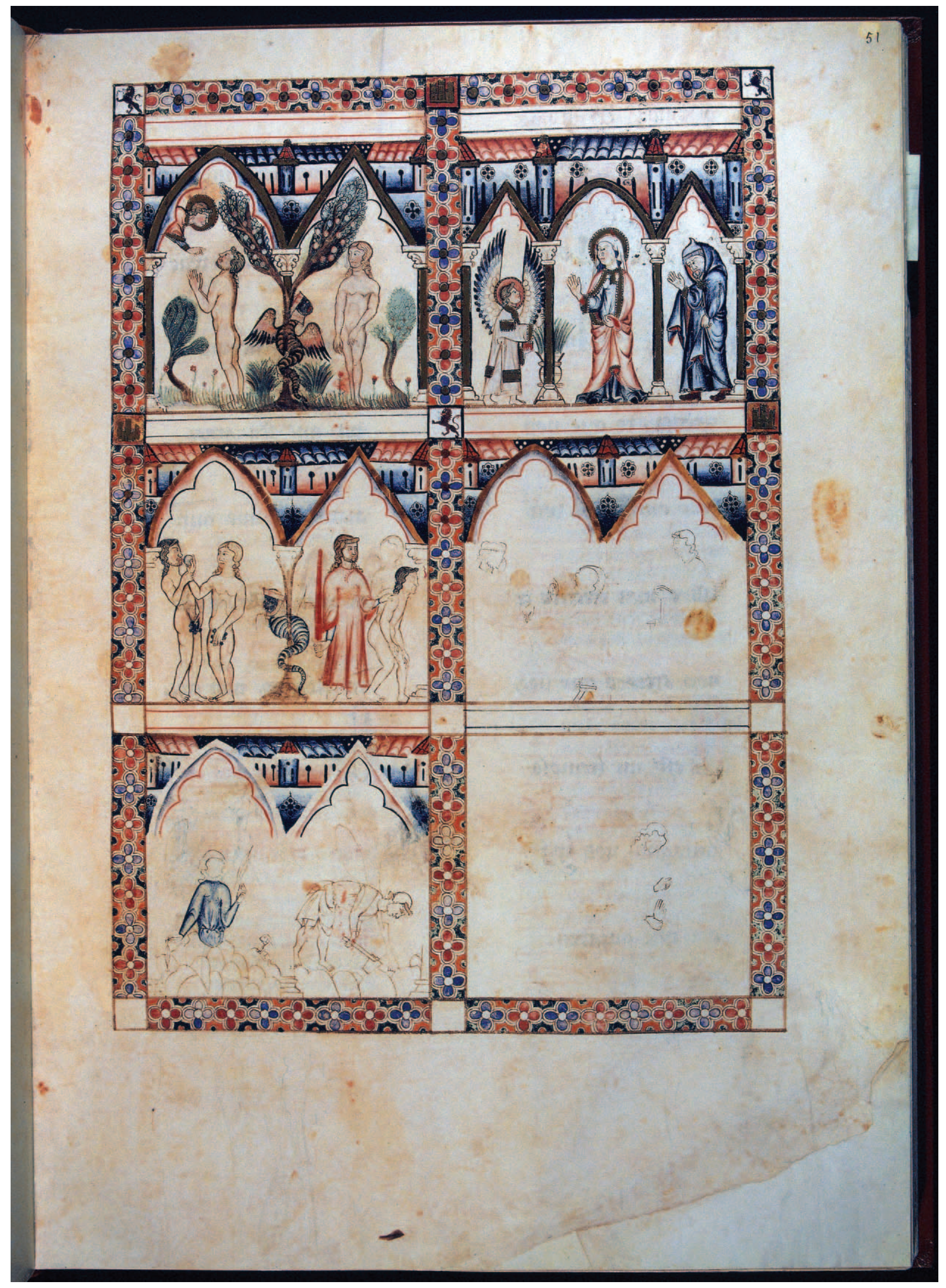

Figure 1. Illustration for Cantiga 320, "Holy Mary Restores the Good Which Eve Lost," fol. 51r, Cantigas de Santa María, early 1290s, Florence, Biblioteca nazionale centrale di Firenze, MS B.R. 20 (photo: Album/Art Resource, NY). 


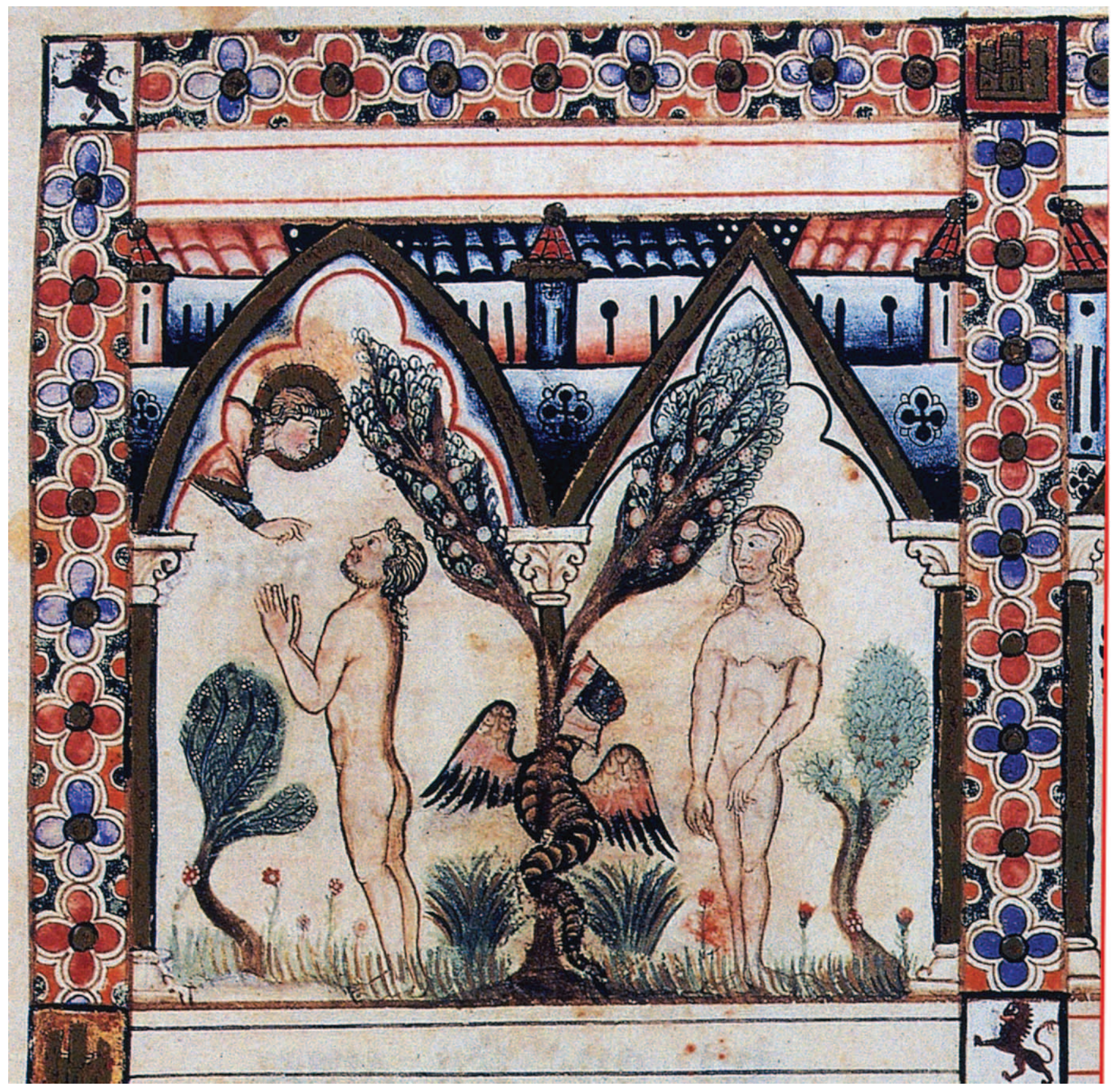

Figure 2. Eve and the serpent, detail of Cantiga 320, fol. 51r, "Holy Mary Restores the Good Which Eve Lost," Cantigas de Santa María, early 1290s, Florence, Biblioteca nazionale centrale di Firenze, MS B.R. 20 (photo: Album/Art Resource, NY).

primarily French Gothic iconographic traditions that inspired it. ${ }^{2}$ Moreover, with one significant exception discussed

2. On the style of the manuscripts, see Ana Domínguez Rodríguez, "Filiación estilística de la miniatura alfonsí," in España entre el Mediterráneo y el Atlántico, Actas del $23^{\circ}$ Congreso internacional de historia del arte, Granada, 1973 (Granada: Universidad de Granada, 1976-78), 2:345-58; Ellen Kosmer and James F. Powers, “Manuscript
Illustration: The Cantigas in Their Contemporary Art Context," in Emperor of Culture: Alfonso X the Learned of Castile and His Thirteenth-Century Renaissance, ed. Robert I. Burns (Philadelphia: University of Pennsylvania Press, 1990), 46-71; Rocío Sánchez Ameijeiras, "Imaxes na teoría da imaxe nas Cantigas de Santa María," in As Cantigas de Santa María, ed. Elvira Fidalgo Francisco (Vigo: Edicións Xerais de Galicia, 2002), 245-330; and Laura Fernández Fernández, “'Este livro, com’achei, fex á onr’ e á loor da Virgen Santa Maria’: el proyecto de las Cantigas de Santa María en el marco del 
below, its exaggerated features and pure black color also set it apart from dark-skinned human figures within the Alfonsine manuscript tradition, in which the brown and beige visages of "Moors" and other ethnic Others tend toward greater naturalism. ${ }^{3}$ Instead, its large white eyes, broad lips, and unnatural blackness coalesce into an exaggerated Africanized stereotype that calls to mind a more distant and deeply layered visual topos, known in the medieval world as the "Ethiopian."

Like a fun-house mirror, the Cantigas serpent fractures, inverts, and recombines its contradictory components-the gender-bending woman-headed hybrid of Gothic tradition and a blackened, racialized physiognomy steeped in discourses of the exotic, distant, and dangerous-in a manner both unprecedented and puzzling. As this article will show, its arresting admixture of traditional forms, crafted by a nowanonymous artist whose motivations we may never fully recover, reflects new visual and epistemic norms just emerging in Iberia at the end of the thirteenth century. These related to the vital but complex role played by dark skin in later medieval Iberian art and thought, where skin color constituted one measure in a series of binaries-good and evil, purity and filth, saved and condemned-that would become central to the visual practices and worldview of a multiethnic and multicultural Castile.

To unpack the semiotic possibilities of the serpent's darkskinned face, this article expands beyond the Iberian peninsula to identify the deep visual and conceptual roots from which the motif emerged, an approach that departs from the close focus on Alfonso's court that is more typical of scholarship on the Cantigas manuscripts. ${ }^{4}$ In doing so, it facilitates

escritorio regio; estado de la cuestión y nuevas reflexiones," in Las Cantigas de Santa María: Códice Rico, Ms. T-I-1, Real Biblioteca del Monasterio de San Lorenzo de El Escorial; estudios interpretivos, ed. Laura Fernández Fernández and Juán Carlos Ruiz Souza (Madrid: Testimonio Compañía, 2011), 45-78, esp. 67-72.

3. Of the many publications concerned with the portrayal of Others in the Cantigas de Santa María, I cite here only a few that specifically address the varied skin colors used in depictions of Muslims: Mercedes García-Arenal, "Los moros en las Cantigas de Alfonso X el Sabio," Al-Qantara: revista de estudios árabes 6, nos. 1-2 (1985): 133-51, esp. 149-50; Peter K. Klein, "Moros y judíos en las 'Cantigas' de Alfonso el Sabio: imágenes de conflictos distintos," in Simposio internacional: el legado de al-Andalus; el arte andalusí en los reinos de León y Castilla durante la Edad Media, ed. Manuel Valdés Fernández (Valladolid: Fundación del Patrimonio Histórico de Castilla y León, 2007), 341-64, esp. 355-56; and Pamela A. Patton, Art of Estrangement: Redefining Jews in Reconquest Spain (College Park: Pennsylvania State University Press, 2012), 114-16.

4. Scholarship on the Cantigas de Santa María is too extensive to be surveyed effectively here. For an overview, see Joseph Snow, The Poetry of Alfonso X: An Annotated Critical Bibliography (12782010) (Woodbridge: Tamesis, 2012), as well as the online bibliography maintained, with frequent updates, by the Centre for the Study broader consideration of the significance of dark skin as a property in late medieval Iberian culture generally, illuminating the important role played there by the topos of the Ethiopian, whose fluctuating connotations of sinfulness, diabolism, and deceptiveness intersected with concurrently developing ideas about women and sexuality to bring powerful new meanings to the Edenic serpent of the Cantigas de Santa María.

\section{The Image in Its Context}

The incomplete manuscript in which Cantiga 320 appears has resided in Florence's National Library since 1861. It is one of two large-scale illustrated codices of the Cantigas de Santa María that were begun for Alfonso X toward the end of his reign, likely in Seville after $1278 .{ }^{5}$ When completed, these two manuscripts would have constituted a two-volume repository for the more than four hundred Marian songs composed in Galician-Portuguese at Alfonso's behest over almost two decades; both were apparently in the king's possession until he

of the Cantigas de Santa Maria of Oxford University (http://csm .mml.ox.ac.uk). A good representation of current scholarship also appears in Fernández Fernández and Ruiz Souza, Las Cantigas de Santa María: Códice Rico. The classic critical edition for the songs, the numeration of which is followed here, is Walter Mettmann, ed., Cantigas de Santa María, 4 vols. (Coimbra: Universidade, 1959-72). For an effective English translation, see Kathleen Kulp-Hill, Songs of Holy Mary of Alfonso X, the Wise: A Translation of the Cantigas de Santa María (Tempe: Arizona Center for Medieval and Renaissance Studies, 2000). More specific works on the Cantigas are cited below as relevant.

5. Both manuscripts have been published in facsimile with a commentary volume: El "Códice Rico" de las Cantigas de Santa María: ms. T.I.1 de El Escorial, coord. Igone Marrodán Prados, 2 vols. (Madrid: Edilán, 1979); and Cantigas de Santa María: edición facsímil del códice B.R. 20 de la Biblioteca nazionale centrale de Florencia, siglo XIII, 2 vols. (Madrid: Edilán, 1989). A traditional account of these and the two unillustrated manuscripts of the Cantigas de Santa María that survive from the thirteenth century is set out as part of a monograph on the Florence codex by Ámparo García Cuadrado, Las Cantigas: el Códice de Florencia (Murcia: Universidad de Murcia, 1993), 29-31. For more recent hypotheses, see Martha E. Schaffer, “The 'Evolution' of the Cantigas de Santa María: The Relationships between MSS T, F, and E," in Cobras e son: Papers on the Text, Music, and Manuscripts of the "Cantigas de Santa María," ed. Stephen Parkinson (Oxford: Legenda, European Humanities Research Centre of the University of Oxford, 2000), 186-213; Manuel Pedro Ferreira, "The Stemma of the Marian Cantigas: Philological and Musical Evidence," Cantigueiros: Bulletin of the Cantigueiros de Santa Maria 6 (1994): 58-98; Laura Fernández Fernández, "Este livro, com' achei," 74-78; and eadem, "Los manuscritos de las Cantigas de Santa María: definición material de un proyecto regio," Alcanate: revista de estudios alfonsíes 8 (2012-13): 81-117, esp. 114-17. 
died in $1284 .{ }^{6}$ The Florence codex mirrors the design of its better-known and more complete companion, often referred to as the Códice Rico, in the monastic library of El Escorial (RBME, MS T-I-1), which preserves nearly two hundred song texts, accompanied by musical notation and, with only one exception, full-page illustrations of either six or twelve panels. ${ }^{7}$ Although it was probably intended to contain another two hundred songs with similar apparatus, the Florence manuscript remained unfinished at the king's death and today contains the texts of just 133 songs, no musical notation, and 48 complete or partial illustrations, several of which were added posthumously. ${ }^{8}$ Although the manuscript's early history remains cloudy, it appears to have become part of the royal library at some point during the fourteenth century. In 1474 it was given by Queen Isabella I to one of her chancellors, Andrés Cabrera, later moving through several private collections in Spain before emerging in the eighteenth century in Florence, where it passed from the Medici family to the Biblioteca Palatina and through several other collections before arriving at the Biblioteca nazionale. ${ }^{9}$

The text of Cantiga 320 appears on fol. 50v of the Florence codex; it is a loor, or song of praise to the Virgin Mary, of a type that appears at regular intervals of ten songs throughout both manuscripts. Bearing the refrain "Santa Maria leva ou ben perdeu Eva" (Holy Mary restores the good which Eve lost), it enumerates the ways in which Eve's loss of paradise was regained by Mary's humility, godliness, wisdom, faith, and understanding. ${ }^{10}$ Its rehearsal of the time-honored typology of Eve and Mary in Christian thought links it with several other

6. Laura Fernández Fernández, "Cantigas de Santa María: fortuna de sus manuscritos," Alcanate: revista de estudios alfonsíes 6 (2008-9): 323-48; eadem, "Historia florentina del códice de las Cantigas de Santa María, Ms. B.R. 20, de la 'Biblioteca Palatina' a la Nazionale Centrale," Reales Sitios: revista del Patrimonio Nacional 164, no. 2 (2005): 18-29; and Rocío Sánchez Ameijeiras, "La fortuna sevillana del códice florentino de las Cantigas: tumbas, textos e imágenes," Quintana 15, no. 1 (2002): 257-73.

7. The illustration of Cantiga 1 contains eight panels, a scheme abandoned in the remaining illustrations, which follow a pattern of a single-page, six-panel illustration for all cantigas except those ending in the number 5 , which are illustrated by two facing pages with twelve panels in all.

8. Fernández Fernández, "Los manuscritos de las Cantigas," 99-105.

9. Sánchez Ameijeiras, "La fortuna sevillana," 258; and Fernández Fernández, "Historia florentina del códice de las Cantigas de Santa María, esp. 20-28. See also Fernández Fernández, "Cantigas de Santa María: fortuna de sus manuscritos," 341-44.

10. The Galician-Portuguese text is given in Mettmann, Cantigas de Santa María, 3 (1964): 173-74; an English translation appears in Kulp-Hill, Songs of Holy Mary, 388. Their respective texts are as follows:

Santa Maria leva / o ben que perdeu Eva cantigas that play on the same typology, a side effect of the widespread rise in Marian devotion that had motivated King Alfonso to commission his collection. ${ }^{11}$

The unfinished illustration that accompanies this text displays several idiosyncrasies beyond the unusual Edenic serpent. One is its method of production: although it was plotted as a full-page series corresponding loosely to the stanzas of the text, only the borders and the upper two of its six planned panels were completed; the third was left only partially painted, and the remaining three were incompletely sketched in light ink. This haphazard production sequence stands in contrast to that of most other illustrations in the Florence manuscript, which were undertaken quite methodically, with borders, underdrawings, bodies, heads, and settings painted in successive phases, likely by a series of specialized artists. When left

O ben que perdeu Eva / pola sa neicidade, / cobrou Santa Maria / per sa grand' omildade. / Santa Maria leva ...

O ben que perdeu Eva / pela sa gran loucura, / cobrou Santa Maria / cona sa gran cordura. / Santa Maria leva ...

O ben que perdeu Eva, / a nossa madr' antiga, / cobrou Santa Maria / u foi de Deus amiga. / Santa Maria leva ...

O ben que perdeu Eva / du perdeu parayso, / cobrou Santa Maria / pelo seu mui bon siso. / Santa Maria leva...

O ben que perdeu Eva / u perdeu de Deus medo, / cobrou Santa Maria / creend' en el mui cedo. / Santa Maria leva...

O ben que perdeu Eva / britand' o mandamento, / cobrou Santa Maria / per bõo entendemento. / Santa Maria leva ...

Quanto ben perdeu Eva / fazendo gran folya, / cobrou a groriosa / Virgen Santa Maria. / Santa Maria leva...

[Holy Mary restores the good which Eve lost. / The good which Eve lost through her temerity, Holy Mary regained through Her great humility. / The good which Eve, our ancient mother, lost, Holy Mary recovered through Her great wisdom. / The good which Eve lost when she lost fear of God, Holy Mary regained by believing in him without question. / The good which Eve lost by breaking the commandment, Holy Mary regained through good understanding. I All the good Eve lost by committing great folly was regained by the glorious Holy Virgin Mary.]

11. For example, Cantiga 60. Ernst Guldan, Eva und Maria: eine Antithese als Bildmotiv (Graz: Böhlau, 1966), 58-59, 178-79, and fig. 39. See also Ana Domínguez Rodríguez, "Imágenes de la mujer en las Cantigas de Santa María," in La imagen de la mujer en el arte español: actas de las terceras Jornadas de investigación interdisciplinaria (Madrid: Ediciones de la Universidad Autónoma de Madrid, 1990), 29-42, esp. 33-34; and Connie L. Scarborough, Women in Thirteenth-Century Spain as Portrayed in Alfonso X's "Cantigas de Santa Maria" (Lewiston, NY: Mellen Press, 1993), 32-38. On the typology more generally, see E. Michael Gerli, "La tipología bíblica y la introducción a los Milagros de Nuestra Señora," Bulletin of Hispanic Studies 62 (1985): 7-14, esp. 8-9; and Marina Warner, Alone of All Her Sex: The Myth and Cult of the Virgin Mary (Oxford: Oxford University Press, 2013), 51-69. 
unfinished, as several illustrations were, all six panels remained at approximately the same stage of execution, whether they contained just borders and underdrawings, bodies with no heads, or near-complete vignettes lacking only their settings. In the illustration for Cantiga 320, the fact that three panels were in final form or nearly so while the other three were barely sketched in suggests the activity of a single artist completing each panel successively to fill preexisting borders. ${ }^{12}$

The independence of this artist is also revealed by modest differences in handling. While his work shares the palette, architectural framing conventions, figure types, and handling of costume and drapery of the other miniatures, its execution is slightly more nervous and graphic, with figures articulated by sharp dark lines rather than the softer modeling typical of the completed works. Facial features are reduced and deflated and architectural structures flatter, more linear, and less assured. These contrasts have led several scholars to identify the Cantiga 320 illustration as one of several introduced to the work just after its primary phase of production. For Gonzalo Menéndez Pidal, Ámparo García Cuadrado, and María Victoria Chico Picaza, this conclusion hinged primarily on style and facture, ${ }^{13}$ while for Ana Domínguez Rodríguez it also related to iconographic differences, specifically the introduction of the woman-headed serpent itself, whose unusual appearance she passed over in favor of emphasizing the motif's broader ties to "moralizing" French Gothic traditions. ${ }^{14}$ These arguments support the likelihood that the Cantiga 320 illustrator was a newcomer to the project, albeit one working only slightly later than the original atelier, as judged by both his assiduous effort to maintain stylistic and material consistency and his work's dissimilarity from the very sloppily painted heads and poorly composed embellishments that were added to the manuscript even later, perhaps in the $1340 \mathrm{~s}^{15}$ This helps to date the Cantiga 320 illustration to the end of the original period of production, perhaps in the early

12. Agustín Santiago Luque, "Marco histórico y texto," in Cantigas de Santa María: edición facsímil del códice B.R. 20, 2:11-121, at 59; and García Cuadrado, Las Cantigas: el Códice de Florencia, 62-73, esp. 72.

13. Gonzalo Menéndez Pidal, "Los manuscritos de las Cantigas: cómo se elaboró la miniatura alfonsí," Boletín de la Real Academia de la Historia 150 (1962): 25-51, at 39; García Cuadrado, Las Cantigas: el Códice de Florencia, 62-73, esp. 72; and María Victoria Chico Picaza, "La ilustración del códice de Florencia," in Cantigas de Santa María: edición facsímil del códice B.R. 20, 2:123-44, at 130-31.

14. Domínguez Rodríguez and Treviño Gajardo, Las Cantigas de Santa María, 169; and Ana Domínguez Rodríguez, "El Libro de los juegos y la miniatura Alfonsí," in the commentary volume to Libros de ajedrez, dados y tablas de Alfonso X el Sabio (Madrid: Patrimonio Nacional, 1987), 98-99.

15. These are discussed by Sánchez Ameijeiras, "La fortuna sevillana," esp. 258, 264-68. 1290s, when, as Laura Fernández Fernández has proposed, the manuscripts might have remained in the royal scriptorium for some time after Alfonso's death. ${ }^{16}$

The Edenic serpent's black, stereotyped face must be original to this phase: its wide lips and enlarged eyes are clearly visible in the underdrawing beneath the dark wash of skin tone, while its linear contours and gray-black pigment are stylistically and materially consistent with other areas of the illustration. ${ }^{17}$ Its unorthodox portrayal thus is best approached as an innovation of its unknown artist, one very much in keeping with the miniature's seemingly ad-hoc production and distinctive execution. Both panels in which it appears depict Adam and Eve in paradise (Fig. 1). The first is fully completed; it shows Adam conversing with an angel while Eve gazes archly at the serpent as it coils around the Tree of Life at the center of the scene. The subsequent panel represents the Virgin, accompanied by Joseph, at the Annunciation, the angelic encounter by which the Virgin's conception of the Savior famously reversed Eve's transgression. ${ }^{18}$ The third panel is not entirely finished, although it clearly contains two consecutive scenes. To the left of the central tree, the serpent watches from its perch as Eve pushes a small round fruit toward Adam's mouth; both now clutch the fig leaves traditionally associated with their fall into sin. To the right, an angel with a flaming sword expels the protoparents from the garden. The serpent here has a veil and wings that are only lightly sketched in and its wide lips lack red pigment, but its face is charcoal black. The fourth panel, evidently planned, like the one above it, to depict a Marian inversion of Eve's misdeed, remains too incompletely outlined for its content to be identified, and the final two panels offer only skeletal hints of their intended

16. Fernández Fernández, “Cantigas de Santa María: fortuna de sus manuscritos," 342-48; and on the subsequent history of this codex, see eadem, "Historia florentina del códice de las Cantigas de Santa María."

17. I base this conclusion on both my own visual analysis and that of Francesca Gallori of the Biblioteca nazionale centrale di Firenze, who kindly consulted with me on this question. The slightly diluted black pigment used in the serpent's face in the first and third panels appears to be the same as that used in its body and in the architectonic elements that frame the scenes, and there are no pentimenti or changes of pigment to suggest that later interventions were made to the serpent's face.

18. As Chico Picaza notes ("La ilustración del códice," 131), Joseph's inclusion in the Annunciation is quite unusual at this date; the closest comparison of which I am aware is a panel of 1393-1410, attributed to Andrés Marzal de Sas and currently in the Museo de Zaragoza; see Juan Luis Rodríguez, "Iconografía josefina en el gótico español," Cahiers de Josephologie 19 (1971): 747-73, at 755. On Joseph in fifteenth-century Annunciations, see Cynthia Hahn, " 'Joseph Will Perfect, Mary Enlighten and Jesus Save Thee': The Holy Family as Marriage Model in the Mérode Triptych," Art Bulletin 68, no. 1 (1986): 54-66. 
imagery: the fifth contains a partial composition of Adam and Eve at work; and the sixth, left almost blank, includes only a faint head and hands. ${ }^{19}$

The two renderings of the serpent in the Cantiga 320 illustration reflect traditions familiar in both Iberia and northern Europe during the first half of the thirteenth century. The figure's depiction with a human head echoes well-known exegeses, chiefly that of Peter Comestor, that describe the devil, already disguised as a serpent, taking on the face of a beautiful young woman to earn Eve's trust because, as Comestor succinctly put it, "like attracts like." ${ }^{20} \mathrm{~A}$ winged human-headed serpent generally resembling the Cantigas example can be found in the mid-thirteenth-century Parisian picture Bible now in the Morgan Library \& Museum (Fig. 3); it too wears a chaplet and veil and slightly lifts its wings as it looks toward Eve. ${ }^{21}$ A slightly earlier Castilian example, displaying long, slender wings and a tiny human head with bobbed blond hair, appears in the Temptation of Adam and Eve that opens the genealogical diagram of the Las Huelgas Beatus, produced in 1220 (Fig. 4) ${ }^{22}$ In keeping with tradition, the serpent's human

19. Chico Picaza has suggested ("La ilustración del códice," 131) that the sixth panel may depict the murder of Abel, but its position suggests that it might have been a Marian scene.

20. Comestor claimed that Satan appeared as a serpent with "the face of a virgin" (virgineum vultum) because "like attracts like" (similia similibus applaudant). See Agneta Sylwan, ed., Petri Comestoris Scolastica historia: Liber Genesis, Corpus Christianorum, Continuatio Mediaevalis 191 (Turnhout: Brepols, 2004), 40; and the discussion by John Flood, Representations of Eve in Antiquity and the English Middle Ages (New York: Routledge, 2011), 72-73. The motif's potential to suggest a specifically sensual temptation is discussed by Nona C. Flores, "'Effigies amicitiae . . veritas inimicitiae’: Antifeminism in the Iconography of the Woman-Headed Serpent in Medieval and Renaissance Art and Literature," in Animals in the Middle Ages: A Book of Essays, ed. Nona C. Flores (New York: Garland, 1996), 167-95; see also Sara Lipton, Images of Intolerance: The Representation of Jews and Judaism in the "Bible moralisée" (Berkeley: University of California Press, 1999), 91. For an argument for the motif's ultimate derivation from a midrashic source, see Shulamit Laderman, "Two Faces of Eve: Polemics and Controversies Viewed through Pictorial Motifs," Images 2, no. 1 (2008): 1-20, esp. 2-4.

21. New York, The Morgan Library \& Museum (hereafter Morgan Library), MS M.638, fol. 1v. On the Morgan Picture Bible, see Sydney C. Cockerell, Old Testament Miniatures: A Medieval Picture Book with 283 Paintings from the Creation to the Story of David (New York: Braziller, 1969); and William Noel and Daniel Weiss, eds., The Book of Kings: Art, War, and the Morgan Library's Medieval Picture Bible (Baltimore: Walters Art Museum, 2002).

22. Morgan Library, MS M.429, fol. 6v. David Raizman identified the human-headed serpent here as among the earliest examples of the type, connecting it with late twelfth-century traditions elsewhere in Europe, including a similar Temptation scene in the Psalter of Blanche of Castile. Blanche's sister Queen Berenguela may have been the patron of this Beatus. Raizman, "The Later Beatus (M.429) in the Morgan Library: Description, Function, Style, and Provenance," in

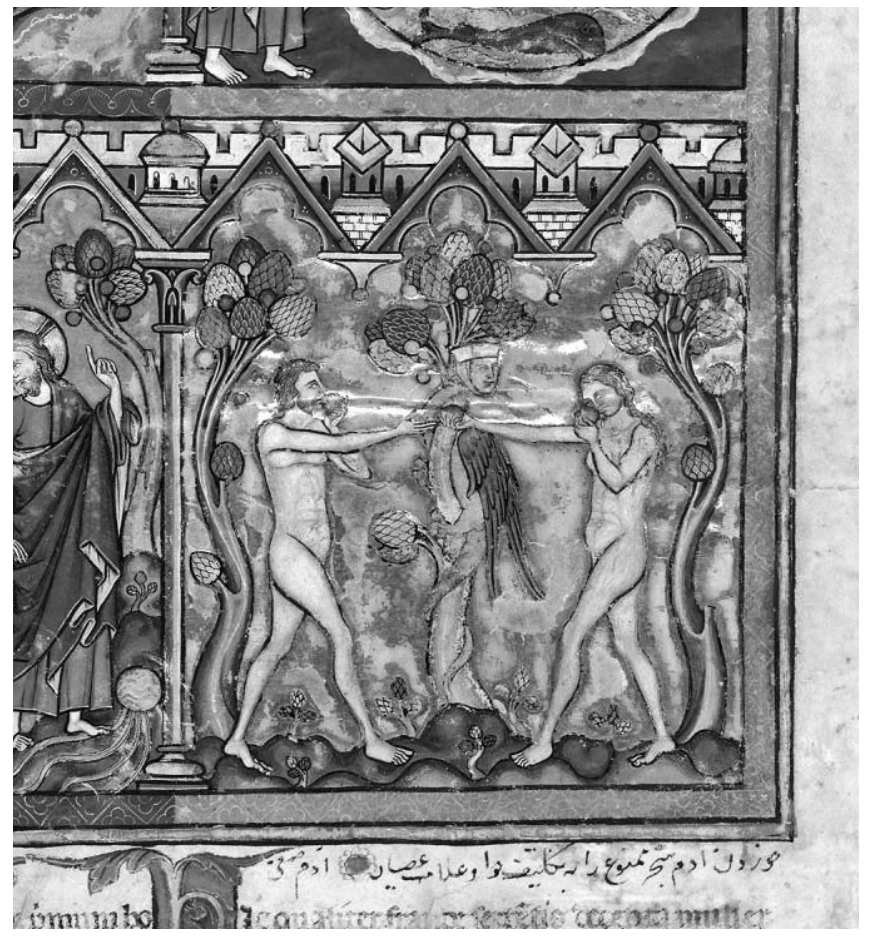

Figure 3. Temptation of Adam and Eve, detail of fol. 1v, Morgan Picture Bible, ca. 1244-54, New York, The Morgan Library \& Museum, MS M.638, purchased by J. Pierpont Morgan [1837-1913] in 1910 (photo: The Pierpont Morgan Library, New York.). See the electronic edition of Gesta for a color version of this image.

face in these images displays the pale skin and small, regular features that were congruent with European aesthetic ideals of the day. ${ }^{23}$ It is, therefore, in the Cantigas serpent's anomalous blackness and outlandish facial features that more particularized meaning must be sought.

\section{The "Ethiopian": Topos and Meanings}

The serpent's dark skin, wide lips, and large white eyes display clear affinities with the multivalent visual topos known in the Middle Ages as the "Ethiopian," a type that emerged in

Estudio del manuscrito del Beato de Las Huelgas M.429, ed. William M. Voelkle et al. (Valencia: Scriptorium, 2004), 212n14, 220-21. On the manuscript and its patronage, see idem, "Prayer, Patronage, and Piety at Las Huelgas: New Observations on the Later Morgan Beatus (M.429)," in Church, State, Vellum, and Stone: Essays on Medieval Spain in Honor of John Williams, ed. Therese Martin and Julie A. Harris (Leiden: Brill, 2005), 235-74.

23. Madeline $H$. Caviness has argued that whiteness acquired intensified significance in thirteenth-century European art. Caviness, "From the Self-Invention of the Whiteman in the Thirteenth Century to The Good, the Bad, and the Ugly," Different Visions: A Journal of New Perspectives on Medieval Art 1 (2008): 57-81 (http://different visions.org/issue1PDFs/Caviness.pdf). 


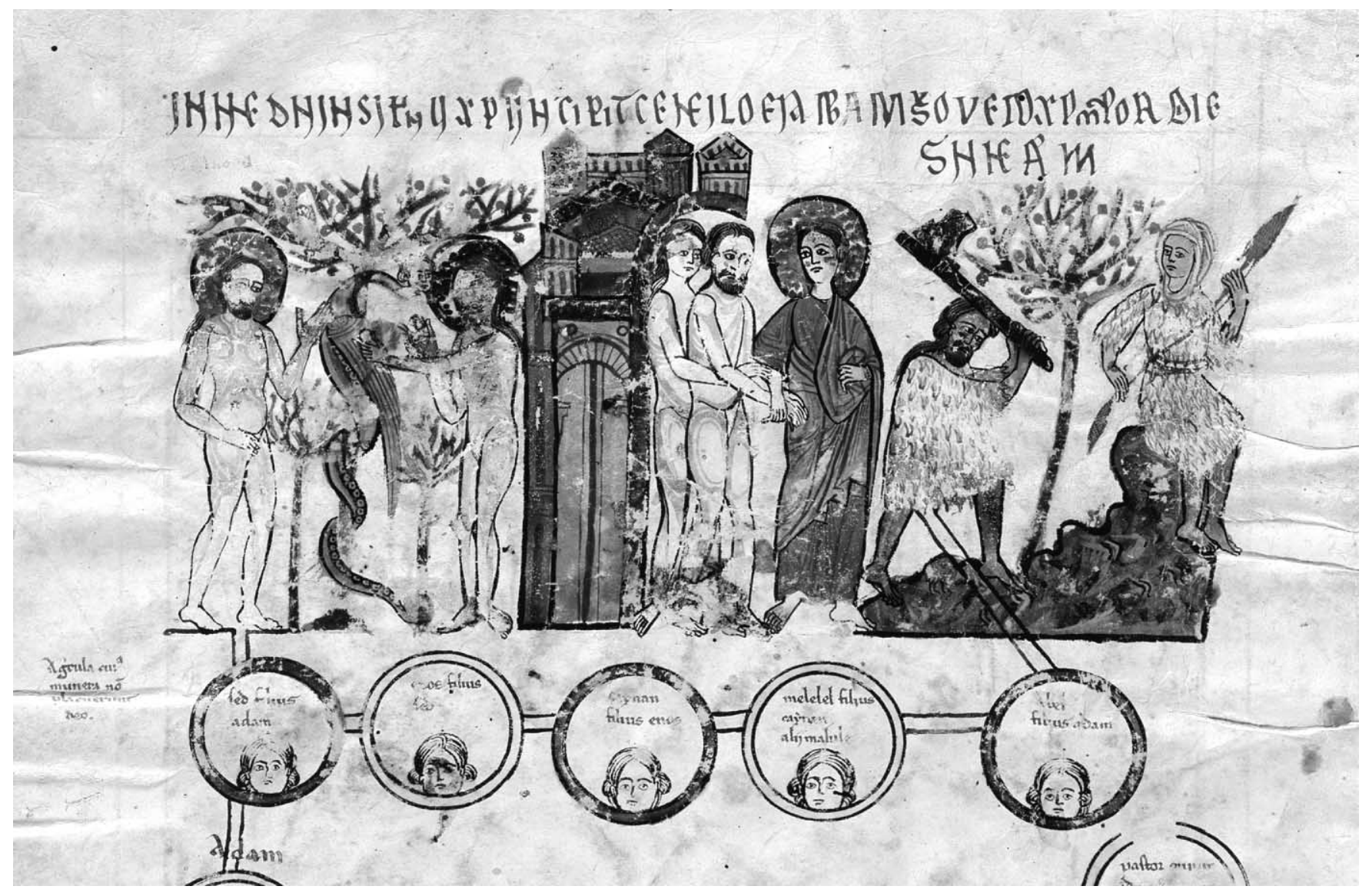

Figure 4. Temptation of Adam and Eve, detail of fol. 6v, Las Huelgas Beatus, 1220, New York, The Morgan Library \& Museum, MS M.429, purchased by J. Pierpont Morgan [1837-1913] in 1910 (photo: The Pierpont Morgan Library, New York.). See the electronic edition of Gesta for a color version of this image.

consistent visual form by the mid-twelfth century in western Europe. Its key features are exemplified in the late twelfthcentury depiction of Christ healing the possessed men of Gadara in the so-called Canterbury Psalter: both the possessed men and the demons issuing from their open mouths exhibit identically dark skin, tightly curled hair, large eyes, and wide, pale lips (Fig. 5). ${ }^{24}$ Both conceptually and visually, the Ethiopian had originated in the ancient Mediterranean world as a semigeographic descriptor for the peoples who inhabited sub-Saharan Africa, whose very dark skin and other somatic properties were attributed to a hot humoral nature caused by the intense sun and heat of the Ethiopian home-

24. Paris, Bibliothèque nationale de France (hereafter BnF), MS lat. 8846, fol. 3v. On this manuscript, see C. R. Dodwell, The Canterbury School of Illumination, 1066-1200 (Cambridge: University Press, 1954), 98-103. While this manuscript is assumed to have traveled to Barcelona by the 1340 s, when several leaves painted in a Catalan style were added to it, the topos of the Ethiopian was by then well known in Iberia and no clear connection with the Canterbury Psalter can be demonstrated. land. ${ }^{25}$ The Ethiopian's distant origins and perceptible physical differences from Graeco-Roman norms, as well as the social roles that dark-skinned peoples came to play in Greek and

25. Debra Higgs Strickland, Saracens, Demons, and Jews: Making Monsters in Medieval Art (Princeton: Princeton University Press, 2003), 79-83; Lloyd A. Thompson, Romans and Blacks (Norman: University of Oklahoma Press, 1989), 86-156; John Block Friedman, The Monstrous Races in Medieval Art and Thought (Syracuse, NY: Syracuse University Press, 2000), 54; and Gay L. Byron, Symbolic Blackness and Ethnic Difference in Early Christian Literature (London: Routledge, 2002), 29-51. More controversial are Frank M. Snowden, Blacks in Antiquity: Ethiopians in the Greco-Roman Experience (Cambridge, MA: Belknap Press, 1970); idem, Before Color Prejudice: The Ancient View of Blacks (Cambridge, MA: Belknap Press, 1983); and idem, "Iconographical Evidence on the Black Populations in Greco-Roman Antiquity" (1979), repr. in The Image of the Black in Western Art, vol. 1, From the Pharaohs to the Fall of the Roman Empire, ed. David Bindman and Henry Louis Gates Jr. (Cambridge, MA: Belknap Press, 2010), 141-250. Jeffrey Tanner offers an important contextualization of these works in his "Introduction to the New Edition" in Bindman and Gates, Image of the Black, 1:1-39. 


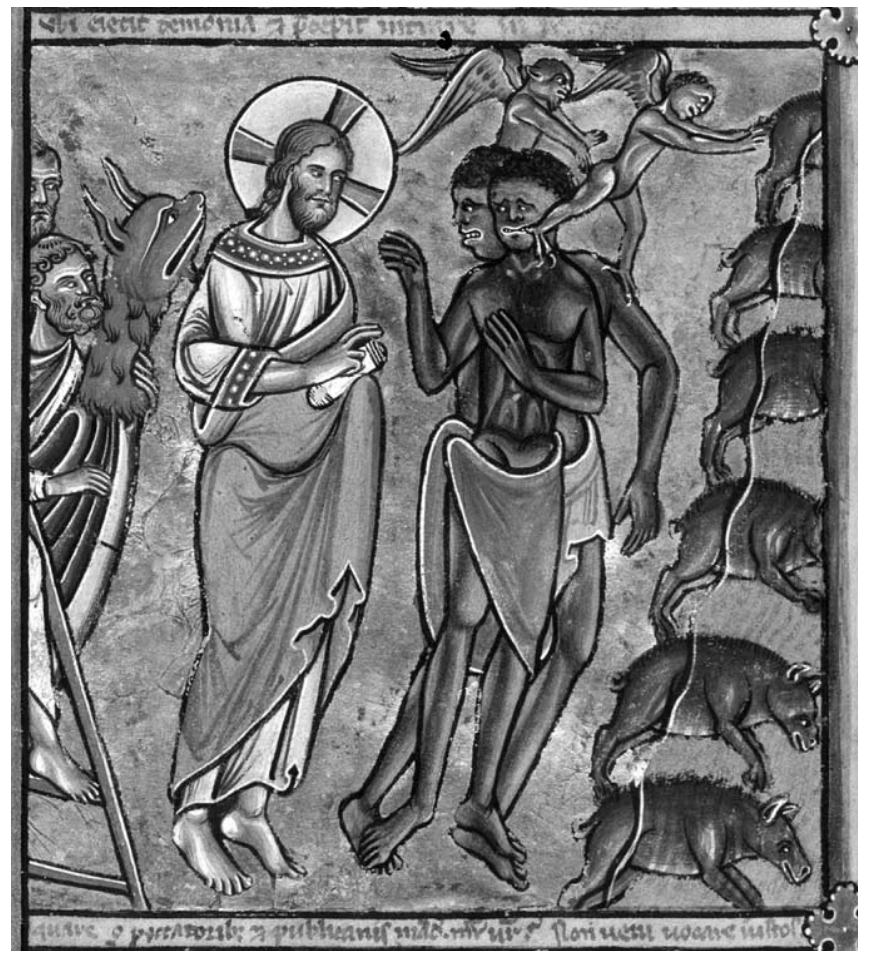

Figure 5. Christ healing the possessed men of Gadara, detail of fol. $3 v$, Canterbury Psalter, late twelfth century, Paris, Bibliothèque nationale de France, MS lat. 8846 (photo: Bibliothéque nationale de France). See the electronic edition of Gesta for a color version of this image.

Roman societies, inspired a wide range of visual representations well before the Middle Ages. Some of these explored the perceived novelty of the Ethiopian's features, whereas others played on widely accepted characterizations of these figures as exotic in appearance and dress, adept as archers, easily subordinated, and sometimes hypersexual. ${ }^{26}$ While typically naturalistic, Greek and Roman renderings of Ethiopians tended to dwell on those features that differed most from the Classical somatic norm: tightly curled hair, full lips, and sharp contrast between white eyes and teeth and very dark skin. In some contexts, these features could be broadened into caricatures with an apotropaic or comic function, exaggerations that foreshadowed medieval imagery. Whether overemphasized or naturalistic, however, it was the combination of Africanized features with dark brown or black skin, not dark skin alone, that distinguished the visual type.

The Ethiopian topos survived the sharp cultural contraction that followed the fall of Rome in western Europe, but by

26. Tanner, "Introduction," 25-39. On the supposed hypersexuality of Ethiopians, see Thompson, Romans and Blacks, 107-9; and John R. Clarke, Looking at Lovemaking: Constructions of Sexuality in Roman Art, 100 B.C.-A.D. 250 (Berkeley: University of California Press, 2001), 119-46. then its naturalism and regional specificity had also receded considerably. While "Ethiopian" could still serve medieval thinkers as a geographic referent, it expanded to encompass a panoply of dark-skinned peoples, real and imagined, who were thought to reside in lands ranging from sub-Saharan Africa to Egypt to India. ${ }^{27}$ The term served simultaneously as a catchall signifier for a host of semimonstrous beings, still called Ethiopians but considerably more fantastical in description, whose extremes of color, shape, and stature furnished imaginative fodder for many an armchair traveler and also provoked association with a host of moral flaws, including lethargy and cowardice but also aggression and barbarity. ${ }^{28}$ No longer an actual people, much less members of a discrete "racial" group even in the nebulous terms by which medieval Europeans understood the notion, ${ }^{29}$ Ethiopians became largely symbolic figments, whose dark skin and resulting imperfect bodies could connote any of the multiple external dangers imagined by a fearful Christendom.

The most forceful of these connotations was an association with sin, a significance anchored both in biblical traditions and in ancient humoral theories. ${ }^{30}$ In patristic and early medieval texts, this gave rise to a symbolic binary in which the Ethiopian's black color reflected a sinful moral state that could only be whitened by conversion. Thus, in his widely known commentary on Psalm 67 (68), St. Jerome could explain that "People of the Ethiopians means those who are black, being covered with the stain of sin," while Didymus the Blind pre-

27. The occasional confusion of Ethiopia and India began in the ancient world: see Friedman, Monstrous Races, 8 .

28. Ibid., 54-55, 64-65; Strickland, Saracens, Demons, and Jews, 79-93; Jean Devisse, "Christians and Black," in The Image of the Black in Western Art, vol. 2, pt. 1, From the Early Christian Era to the "Age of Discovery": From the Demonic Threat to the Incarnation of Sainthood, ed. David Bindman and Henry Louis Gates Jr., new ed. (Cambridge, MA: Belknap Press, 2010), 31-72, esp. 46-55.

29. This topic is far too broad to be addressed adequately here, but see David M. Goldenberg, "The Development of the Idea of Race: Classical Paradigms and Medieval Elaborations," International Journal of the Classical Tradition 5, no. 4 (1999): 561-70; William Chester Jordan, "Why Race?," Journal of Medieval and Early Modern Studies 31, no. 1 (2001): 165-73; Robert Bartlett, "Medieval and Modern Concepts of Race and Ethnicity," Journal of Medieval and Early Modern Studies 31, no. 1 (2001): 39-56; Jeffrey J. Cohen, "On Saracen Enjoyment: Some Fantasies of Race in Late Medieval England and France," in Medieval Identity Machines (Minneapolis: University of Minnesota Press, 2003), 188-221; Geraldine Heng, "The Invention of Race in the European Middle Ages, I: Race Studies, Modernity, and the Middle Ages," Literature Compass 8, no. 5 (2011): 315-31; and eadem, "The Invention of Race in the European Middle Ages, II: Locations of Medieval Race," Literature Compass 8, no. 5 (2011): 332-50.

30. Strickland, Saracens, Demons, and Jews, 37-39; Byron, Symbolic Blackness, 55-76; and Snowden, Blacks in Antiquity, 196-205. 
sented Ethiopians' blackness as reflecting ignorance of God and envisioned their delivery from sin as a literal washing away of their dark color inspired by Psalm 50 (51):9, "Thou shalt wash me, and I shall be made whiter than snow."31 Popularized by Gregory the Great's oft-repeated musing, likely inspired by Jeremiah 13:23, about the difficulty of washing the Ethiopian white, this trope became a commonplace in medieval and later religious writing. ${ }^{32}$

The medieval equation of blackness with sin was complicated by certain cases in which figures described as black were clearly positive in nature; the "black but beautiful" Bride in the Song of Songs is the best known of these. Such figures often were understood to have become sinless despite their appearance; Honorius Augustodunensis, for example, explained that since the Songs text describes the Bride's skin as darkened by the sun, her color was an accident incidental to her moral state. ${ }^{33}$ In other figures, such as the Queen of Sheba or St. Maurice, dark skin functioned as a primarily benign indication of distant and pagan origins rather than a mark of moral insufficiency. ${ }^{34}$ Indeed, such figures' ability to

31. Jean-Marie Courtès, “The Theme of 'Ethiopia' and 'Ethiopians' in Patristic Literature," in Bindman and Gates, Image of the Black, 2, pt. 1:199-214, esp. 203-4, 211; for Jerome, see also Byron, Symbolic Blackness, 55-56. An excellent handling of the imbrication of sin and blackness in early monastic writing, a sphere in which it was richly developed, is David Brakke, Demons and the Making of the Monk: Spiritual Combat in Early Christianity (Cambridge, MA: Harvard University Press, 2006), 157-81.

32. Gregory I, Epistola ad Domitianum Metropolitanum 3.67, in Patrologiae Cursus Completus: Series Latina, ed. J.-P. Migne, 221 vols. (Paris: Garnier, 1844-64) (hereafter Migne, $P L$ ), 77 (1849): col. 668C; and Devisse, "Christians and Black," 53; for subsequent medieval examples, 243n245. For an illustration of such thinking in early medieval visual imagery, see Dorothy Hoogland Verkerk, "Black Servant, Black Demon: Color Ideology in the Ashburnham Pentateuch," Journal of Medieval and Early Modern Studies 31, no. 1 (2001): 57-77, esp. 63-64. On the trope's origins and longer legacy, see Jean Michel Massing, "From Greek Proverb to Soap Advert: Washing the Ethiopian," Journal of the Warburg and Courtauld Institutes 58 (1995): 180-201, esp. 182.

33. "I am black but beautiful, O ye daughters of Jerusalem, as the tents of Cedar, as the curtains of Solomon. Do not consider me that I am brown, because the sun hath altered my colour: the sons of my mother have fought against me, they have made me the keeper in the vineyards: my vineyard I have not kept" (Song of Songs 1:5-6, Douay-Rheims ed.). See Honorius Augustodunensis, Expositio in Cantico Canticorum 1.4, in Migne, PL, 172 (1854): cols. 367D-370B.

34. Madeline $\mathrm{H}$. Caviness argues for greater variability in the meaning of the queen's skin color in "(Ex)changing Colors: Queens of Sheba and Black Madonnas," in Architektur und Monumentalskulptur des 12.-14. Jahrhunderts: Produktion und Rezeption; Festschrift für Peter Kurmann zum 65. Geburtstag (Bern: Peter Lang, 2006), 553-70. On St. Maurice, see Gude Suckale-Redlefsen, Mauritius, der heilige Mohr = The Black Saint Maurice (Houston: Menil Foundation, 1987); and Jean Devisse, "A Sanctified Black: Maurice," in supersede the generally, although still not exclusively, negative qualities related to dark skin might have been seen as highlighting the exceptionality of their virtuous condition, a dynamic that testifies in its own way to the profundity of the skin-sin connection in Western culture.

\section{Disguise and Temptation}

The long-standing connection of Ethiopian blackness with sin readily invited further associations, among which was a linkage with the devil. ${ }^{35}$ Early monastic texts frequently envisioned Satan or his followers in the form of disruptive Ethiopians. Macarius of Alexandria described little Ethiopian boys who during services pressed on monks' eyelids to make them droop, stuck fingers in their mouths to make them yawn, and induced unholy visions while they were prostrate in prayer; John Cassian told of a monk who was tormented to distraction by an Ethiopian who ran around his cell shooting arrows at him while he prayed; and Gregory the Great described a monk's inability to get through his prayers because the devil, disguised as a small black boy, kept tugging on his cloak. ${ }^{36}$ Their imagery had a robust afterlife: Ralph Glaber's eleventh-century Five Books of the Histories recounts how the false relics of St. Justus, once installed in a new monastery at Susa, were exposed when "black Ethiopians" (formas nigrorum Ethiopum) crept out of the reliquary at night, and Peter the Venerable incorporated a variant of Cassian's arrowshooting Ethiopian in his twelfth-century De miraculis. ${ }^{37}$ Jacobus de Voragine's enormously popular Legenda aurea (Golden Legend), compiled about 1260, included demonic Ethiopians in a number of saints' lives, among them the "black and naked" Ethiopians who issue from idols denounced by SS. Simon and Jude in the city of Samir and the chained

Bindman and Gates, Image of the Black, 2, pt. 1:139-94. Another positive black figure who emerged in the late Middle Ages was the black Magus; see Paul H. D. Kaplan, The Rise of the Black Magus in Western Art (Ann Arbor, MI: UMI Research Press, 1985).

35. Strickland, Saracens, Demons, and Jews, 80-83; Thompson, Romans and Blacks, 112-13; and Devisse, "Christians and Black," 55-63.

36. David Brakke, "Ethiopian Demons: Male Sexuality, the BlackSkinned Other, and the Monastic Self," Journal of the History of Sexuality 10, nos. 3-4 (2001): 501-35; see 508-9, 526, for the examples cited here, further contextualized in idem, Demons and the Making of the Monk, 159-62. See also Philip Mayerson, "Anti-Black Sentiment in the Vitae Patrum," Harvard Theological Review 71, nos. 3-4 (1978): 304-11; and Devisse, "Christians and Black," 55-62.

37. "Videbat, et ecce daemon, parvi et nigerrimi Aethiopis specie assumpta, lecto ejus adstabat" (Peter the Venerable, De miraculis 1.8, in Migne, PL 189 [1854]: col. 869D). See also Ralph Glaber, The Five Books of the Histories 4.3.7-8, ed. and trans. John France (Oxford: Clarendon Press, 1989), 184-85. 


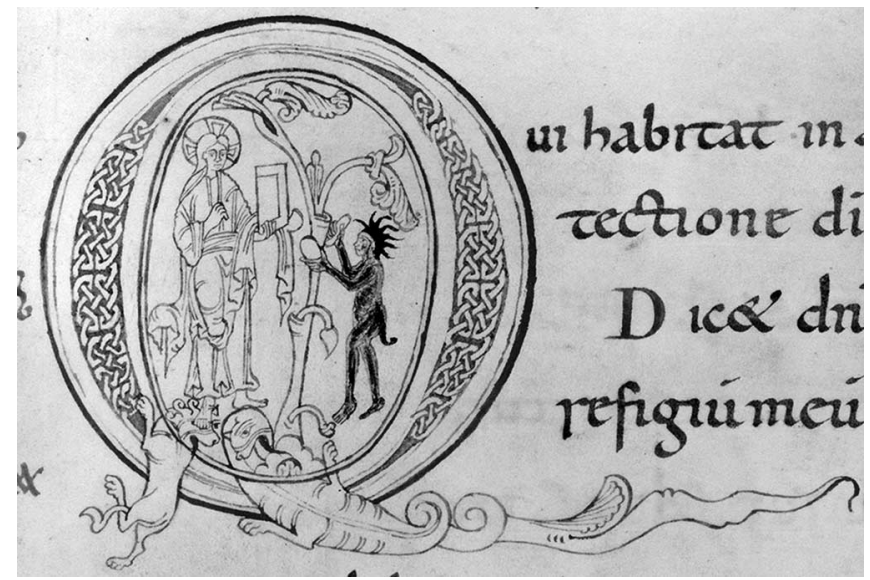

Figure 6. Temptation of Christ, detail of fol. 101r, Odbert Psalter, ca. 1000, Boulogne-sur-Mer, Bibliothèque municipale, MS 20 (photo: Image of the Black in Western Art Archive, by permission). See the electronic edition of Gesta for a color version of this image.

Ethiopian, "black as soot," who appears at St. Bartholomew's command when he converts the king of India. ${ }^{38}$ A central theme in all such narratives, both patristic and hagiographic, was the recognizability of such camouflage as demonic: while it nominally disguised the devil, it could also serve as the tipoff to the diabolical presence.

Visual images of demonic Ethiopians, which began to proliferate in European art around the beginning of the eleventh century, play effectively on both the stereotype's moral connotations and its metonymic ability to signal the devil's presence, as already noted in the case of the Canterbury Psalter. ${ }^{39}$ Also similar to the textual tradition is the frequency with which an Ethiopian disguise appears specifically in episodes of temptation. An early exemplar can be seen in an initial in the Odbert Psalter, produced in St.-Omer around 1000. Enclosed within the penwork Q of "Qui habitat" (Psalm 90 [91]), a vignette of the Temptation of Christ portrays the Savior confronted by a tiny black man with a short tail, a flattened nose, and wild, curling hair (Fig. 6). ${ }^{40}$ While this figure displays only a few features of the subsequently more codified Ethiopian stereotype, it constitutes a logical precursor.

38. Jacobus de Voragine, The Golden Legend: Readings on the Saints, trans. William Granger Ryan (Princeton: Princeton University Press, 1993), 2:112, 262. For the Latin, see the critical edition by Giovanni Paolo Maggioni, Iacopo da Varazze, Legenda aurea (Florence: SISMEL-Edizioni del Galluzzo, 1998), 2:830-40, at 833, and 2:1079-87, at 1086.

39. Strickland, Saracens, Demons, and Jews, 80-81, fig. 29; and Devisse, "Christians and Black," 62.

40. Boulogne-sur-Mer, Bibliothèque municipale, MS 20, fol. 101r. Rainer Kahsnitz, "Der Christologische Zyklus im Odbert Psalter," Zeitschrift für Kunstgeschichte 51, no. 1 (1988): 33-125, esp. 88.

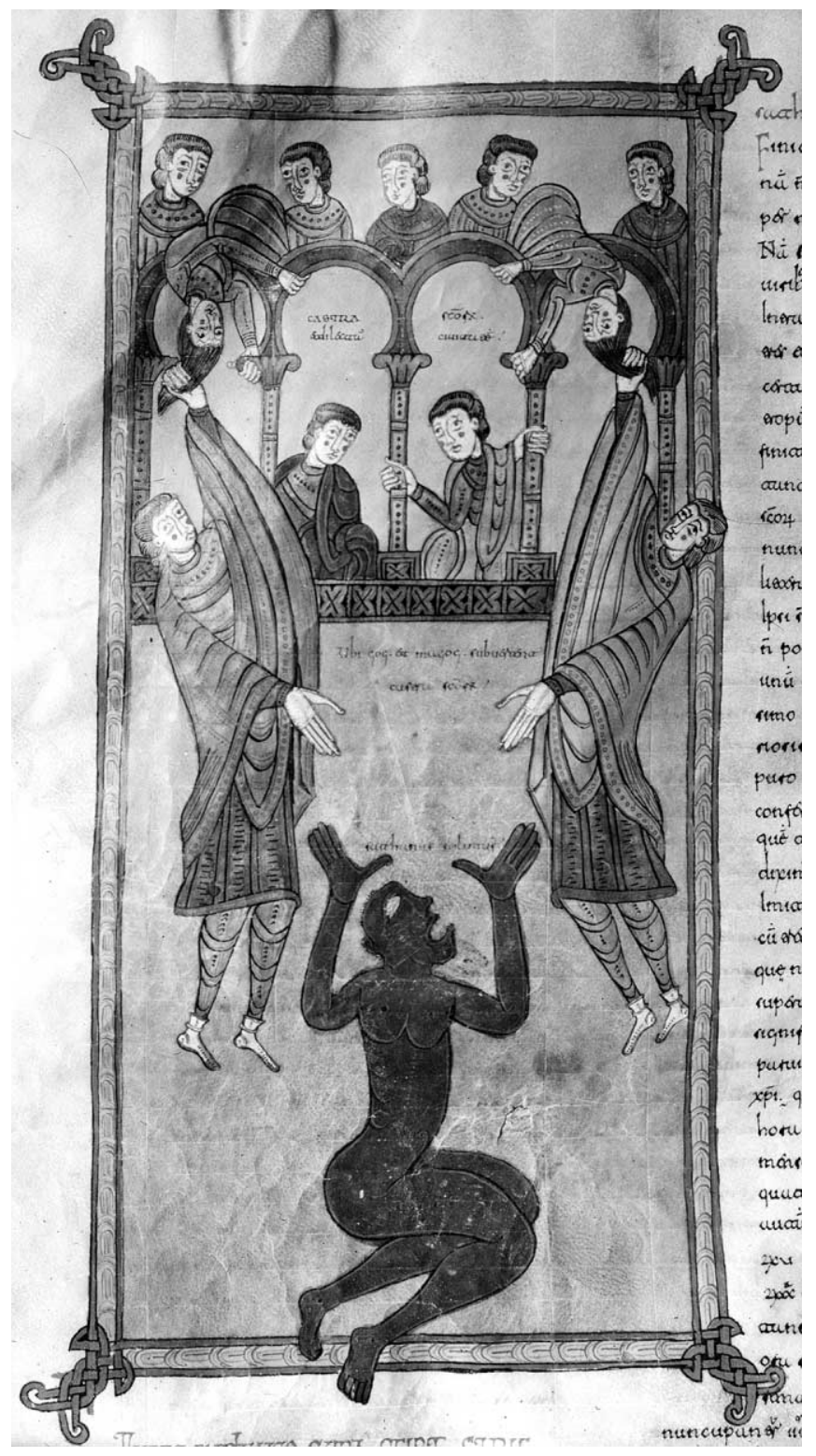

Figure 7. Satan tempting Gog and Magog, fol. 155v, Burgo de Osma Beatus, 1086, Burgo de Osma, Archivo de la Catedral, MS 1 (photo: Institut Amatller d'Art Hispànic).

In Iberia itself, a more humanoid, Africanized Satan appears in the Burgo de Osma Beatus, produced in the Leonese monastery of Sahagún in 1086 (Fig. 7). ${ }^{41}$ Here, Satan tempts Gog and Magog by taking the form of a nude black man with short curly hair and large whitened eyes, a portrayal that deviates sharply from the bestial winged hybrid that is typically included in this scene in other Beatus manuscripts. This inconsistency might have been what prompted the addi-

41. Burgo de Osma, Archivo de la Catedral, MS 1, fol. 155v. 
tion here of an inscription, "SATHANAS SOLUTUS" (Satan unbound) to confirm the figure's identity. Its deviation from the formidable Beatus tradition accords with John Williams's characterization of the Burgo de Osma manuscript as "the least conservative" of its family, suggesting an openness to the Ethiopian topos that foreshadows the cantiga illustration. ${ }^{42}$

The exaggerated Satan-Ethiopian of the Burgo de Osma Beatus must be set apart from the wider array of dark-skinned figures that proliferated in the art of medieval Iberia from the twelfth century onward. As elsewhere in Europe at that time, Iberian artists sometimes pressed brown-skinned figures with African features into use as stock characters, such as servants and soldiers, or to represent actual black Africans or even Muslims ${ }^{43}$ Such widely varied images, which often share skin color or other physiognomic elements with the specifically satanic Ethiopians under discussion here, may be differentiated from them by the Ethiopians' predominantly symbolic role, their often greater degree of physiognomic or somatic exaggeration, and their consistently supernatural connotations.

All these features are at play in a second dark-skinned Iberian Satan, which appears in an early twelfth-century fresco of the Temptation of St. Martin in the Panteón de los Reyes in San Isidoro, León. Located on the lower section of an intrados next to the famous Pantocrator fresco of the central vault, it portrays Martin's antagonist as a small, richly garbed man with the dark skin, curly hair, large eyes, and flat-bridged nose of the Ethiopian formula (Fig. 8). His identity is signaled overtly by the adjacent inscription, "S[AN[C[TU]S MARTINUS DIXI[T] VADE SATANAS" (St. Martin said, "Go [away], Satan!"). ${ }^{44}$ As Therese Martin has shown, the scene resonates generally with Sulpicius Severus's early fifth-century life of the saint, and it echoes several subse-

42. John W. Williams, The Illustrated Beatus: A Corpus of the Illustrations of the Commentary on the Apocalypse, vol. 4, The Eleventh and Twelfth Centuries (London: Harvey Miller, 2002), 17.

43. On the black soldier type, who was often cast specifically as a torturer or executioner, see Devisse, "Christians and Black," 64-72. The greater diversity with which black and African types were depicted in medieval Iberia and the Mediterranean merits deeper exploration than it has received to date; see, however, Jean Devisse, "The Black and His Color: From Symbols to Realities," in Bindman and Gates, Image of the Black, 2, pt. 1:73-137, esp. 77-89, 129-37; and, in the same volume, Paul H. D. Kaplan, "Introduction to the New Edition," 1-30, esp. 12-18; and idem, "Black Africans in Hohenstaufen Iconography," Gesta 26, no. 1 (1987): 29-36. For Spain, although with an emphasis on black figures' symbolic links with Muslims, see Inés Monteira Arías, El enemigo imaginado: la escultura románica hispana y la lucha contra el Islam (Toulouse: CNRS-Université de Toulouse-Le Mirail, 2012), 479-88.

44. Rose Walker, "The Wall Paintings in the Panteón de los Reyes at León: A Cycle of Intercession," Art Bulletin 82, no. 2 (2000): 200225 , at 209-10.

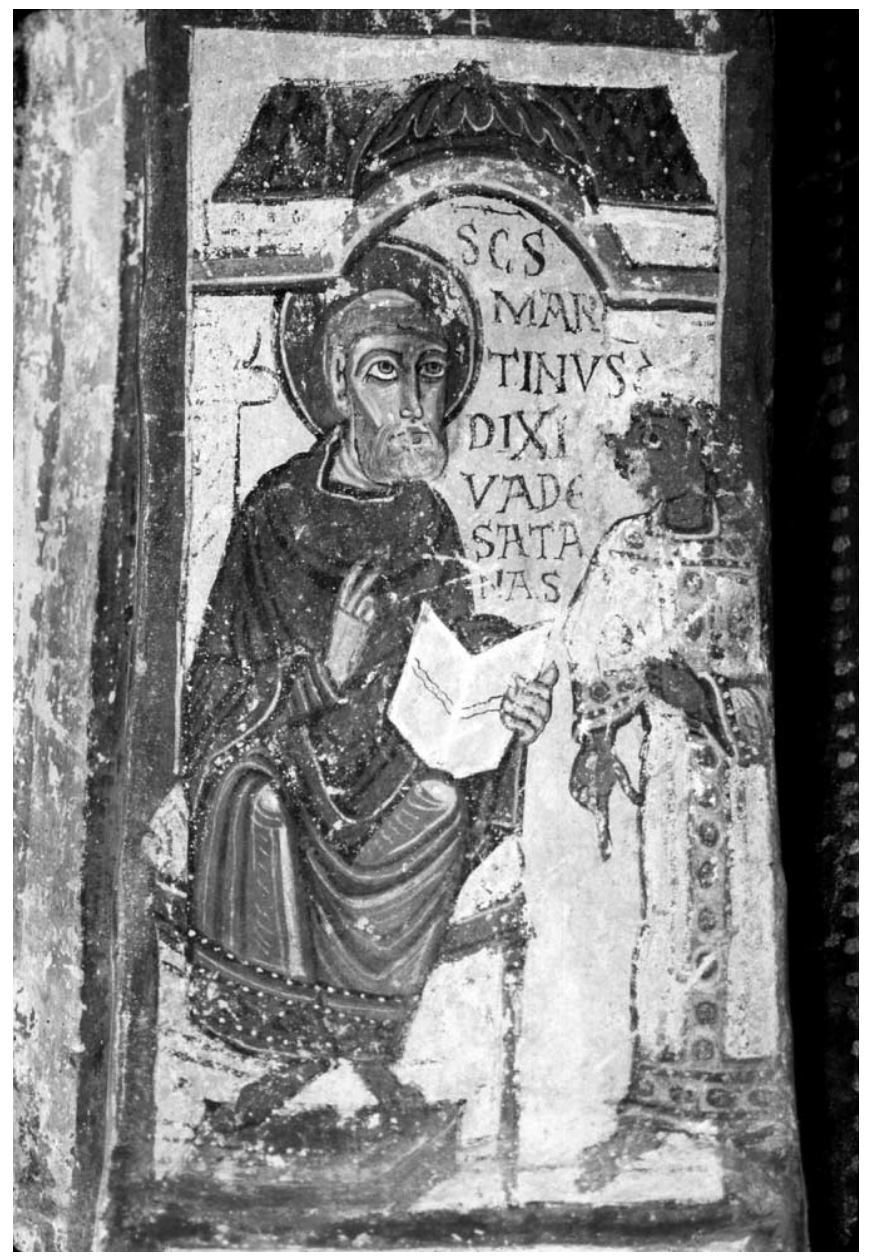

Figure 8. Temptation of St. Martin, detail of fresco in the Panteón de los Reyes, ca. 1100, San Isidoro, León (photo: James D'Emilio, by permission). See the electronic edition of Gesta for a color version of this image.

quent vitae, including that in the Legenda aurea, in representing the devil's appearance in royal dress in an effort to convince St. Martin that he is Christ. ${ }^{45}$ Neither Sulpicius's nor Jacobus de Voragine's account describes the devil as taking Ethiopian form, however, and from a medieval perspective, the inconsistency of such stereotypes with the figure's kingly attire would seem to militate against it. In the fresco, then, the Ethiopian disguise introduces a new layer to the tradition: while Satan's royal finery gestures at concealing his identity

45. Therese Martin, Queen as King: Politics and Architectural Propaganda in Twelfth-Century Spain (Leiden: Brill, 2006), 148-49. While Martin suggests that this figure may be female, its uncovered head and masculine attire are consistent with its narrative treatment as male. For the Golden Legend, see Jacobus de Voragine, Golden Legend, 2:298. 


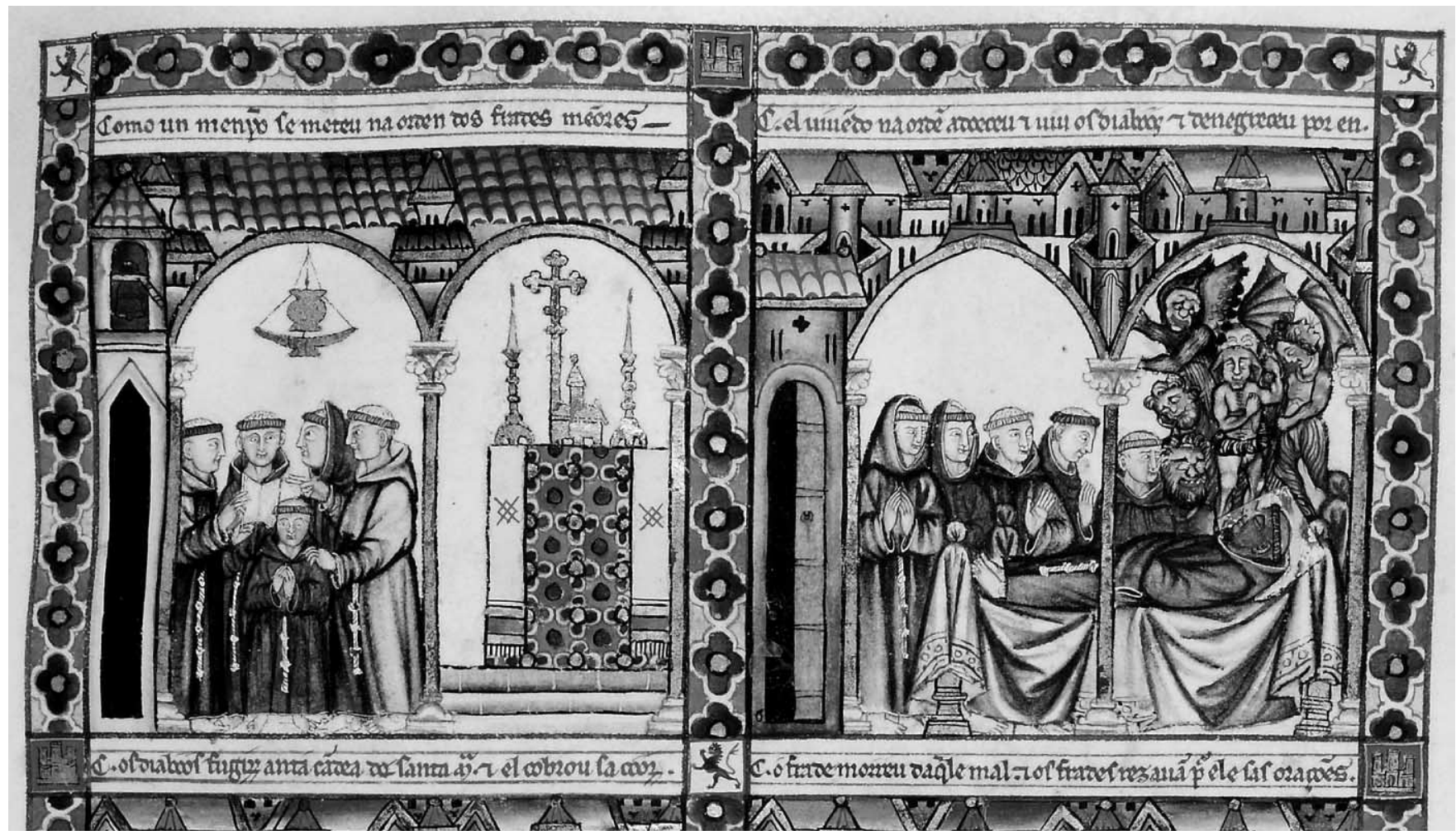

Figure 9. Illustration for Cantiga 123, "How Holy Mary Saved a Friar Minor from the Devils When He Was About to Die and Writhed in Fear of Them," fol. 174r, Cantigas de Santa María, ca. 1280, Madrid, Real Biblioteca del Monasterio de San Lorenzo de El Escorial, MS T-I-1 (photo: (c) Patrimonio Nacional). See the electronic edition of Gesta for a color version of this image.

from the saint, his dark, outlandish countenance nods to the knowing viewer.

As northern Iberian works produced long before the Cantigas de Santa María, the Burgo de Osma illumination and the León fresco signal the availability of the Ethiopian topos as a form of satanic disguise within Iberian visual tradition, offering a suggestive precedent for the late thirteenthcentury images of the illustrated Cantigas de Santa María manuscripts. The illustrators of the Cantigas clearly recognized the demonic potential of dark skin: their repeated use of black, brown, gray, or dark blue pigments to depict Satan, his followers, and occasionally his victims complements the songs' own references to the devil as black. ${ }^{46}$ One tandem

46. See Maria Idalina Resina Rodrigues, "Os afazeres do demónio nas Cantigas de Santa Maria de Afonso X," in Estudos ibéricos da cultura à literatura: séculos XIII a XVII (Lisbon: ICALP, 1987), 403-28, esp. 418-19. She cites as examples Cantigas 3 ("mais ca pez negro"), 47 ("negro come pez"), 82 ("negro de coor"), 119 ("negro"), and 298 ("negro chuz ca pez"). See also Rafael Ocasio, "Ethnic Underclass Representation in the Cantigas: The Black Moro as a Hated Character," in Estudios alfonsinos y otros escritos: en homenaje a John Esten Keller y a Anibal A. Biglieri, ed. Nicolás Toscano (New York: National Endowment for the Humanities, 1991), 183-88, esp. 186-87. reference of this kind appears in Cantiga 123 in the Escorial volume, which describes how a dying monk became twisted and black ("se torceu e parou-sse negro") like the devils that surrounded him in his final hour, then whitened again when a companion lit a candle to the Virgin. The illustration on fol. $174 \mathrm{r}$ shows the monk's face changing from white to black as he is encircled by a cloud of demons (Fig. 9), then to white in the next panel when the candle is lit. ${ }^{47}$ More direct reference to the devil's blackness is found in Cantiga 74 in the same manuscript (fol. 109r; Fig. 10), where the frescoed image of Satan produced by an artist who had painted him "uglier than anything else" (mais feo d'outra ren) is rendered in deep black and gray, while the devil who appears in person to threaten the artist is both described and depicted as "blacker than pitch" (mais negro ca pez). ${ }^{48}$

47. Kulp-Hill, Songs of Holy Mary, 152; and Mettmann, Cantigas de Santa María, 2 (1961): 63-64.

48. Kulp-Hill, Songs of Holy Mary, 96; Mettmann, Cantigas de Santa María, 1 (1959): 216-17; and, for the image, see Alejandro García Avilés, "Imágenes 'vivientes': idolatría y herejía en las Cantigas de Alfonso X el Sabio," Goya: revista de arte 321 (2007): 324-42, at 339 , fig. 11 . 


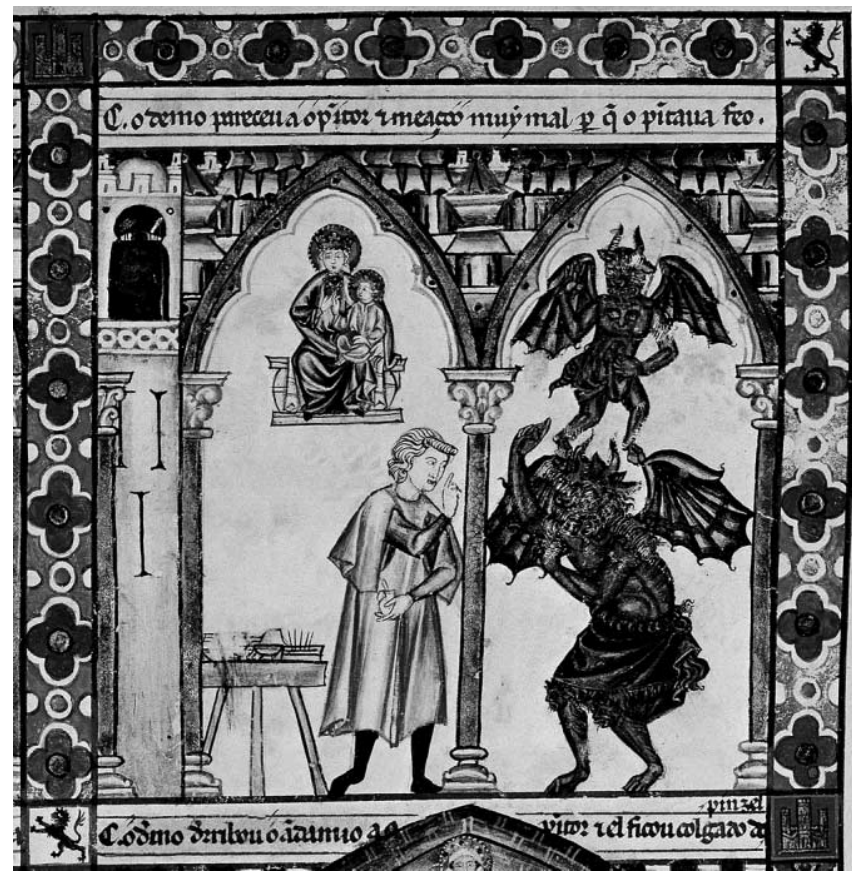

Figure 10. Illustration for Cantiga 74, "How Holy Mary Saved the Painter Whom the Devil Had Tried to Kill Because He Painted Him Ugly, fol. 109r, Cantigas de Santa María, ca. 1280, Madrid, Real Biblioteca del Monasterio de San Lorenzo de El Escorial, MS T-I-1 (photo: Album/Art Resource, NY). See the electronic edition of Gesta for a color version of this image.

Two illustrations in the Escorial manuscript, moreover, endow Satan with a specifically Ethiopian likeness. Like so many earlier narratives in which the devil adopted this guise, the tales concern monastic temptation. Cantiga 47 describes how Satan confronted a monk who had overindulged in the stores of the monastic wine cellar. The devil makes his appearances in three different forms: a bull, a lion, and "a tall, thin man, ... all shaggy and black as pitch" (en figura d'ome ... longu' e magr' e veloso / e negro come pez). ${ }^{49}$ The illustration portrays this figure as a humanoid with dark gray skin, skinny legs, shaggy goatlike breeches, and spiky black hair suggestive of the Ethiopian topos (fol. 70r; Fig. 11). Here, both the tale's narrative formula, which describes a monk alone and vulnerable to devilish advances, and the repetition of the phrase "black as pitch" hark back to earlier medieval accounts of monastic temptations in which Satan takes a similar form.

The devil's guise in Cantiga 82 is more overtly Ethiopian. The lively story concerns the Virgin's rescue of a Carthusian

49. Kulp-Hill, Songs of Holy Mary, 63; and Mettmann, Cantigas de Santa María, 1:137-38.

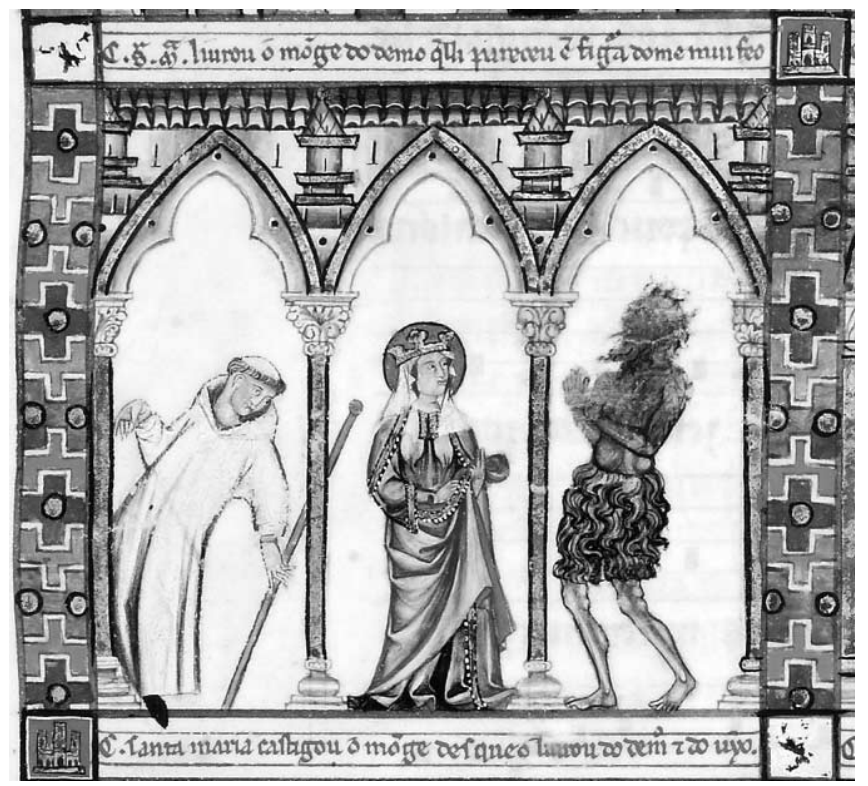

Figure 11. Monk threatened by Satan, detail of Cantiga 47, "How Holy Mary Saved the Monk Whom the Devil Had Tried to Frighten to Seize His Soul," fol. 70r, Cantigas de Santa María, ca. 1280, Madrid, Real Biblioteca del Monasterio de San Lorenzo de El Escorial, MS T-I-1 (photo: (C) Patrimonio Nacional). See the electronic edition of Gesta for a color version of this image.

friar from a mob of demons who come to him in the form of swine. It tells how the friar was sleeping in his cell when he was surrounded by the terrifying herd, followed by the devil in the form of "a black man" (un ome negro de coor). ${ }^{50}$ When the swine explain that they cannot attack their frightened victim because of his saintliness, the devil threatens to tear him to bits with his hooks but is prevented when the friar's prayers bring the Virgin Mary to drive the interlopers away with a stick.

The devil is shown first in the second panel, where he enters the cell on the heels of his multicolored, winged swine (fol. 120r; Fig. 12). In this and his next appearance, he displays all the traditional features of the Ethiopian topos, with very dark brown skin and an exaggerated physiognomy marked by oversize white eyes and teeth, protruding red lips, and short, unruly hair (Fig. 13). When in the fourth panel the Virgin's arrival prompts the entire company to revert to demonic form, the swine become upright, cloven-footed hybrids, and Satan is revealed to be a monster with twisted horns, floppy doglike ears, and pink wings. His Ethiopian disguise here, as in the Beatus and León images (Figs. 7-8), is fundamentally self-referential, both obscuring and revealing his true nature.

50. Kulp-Hill, Songs of Holy Mary, 106; and Mettmann, Cantigas de Santa María, 1:238-39 


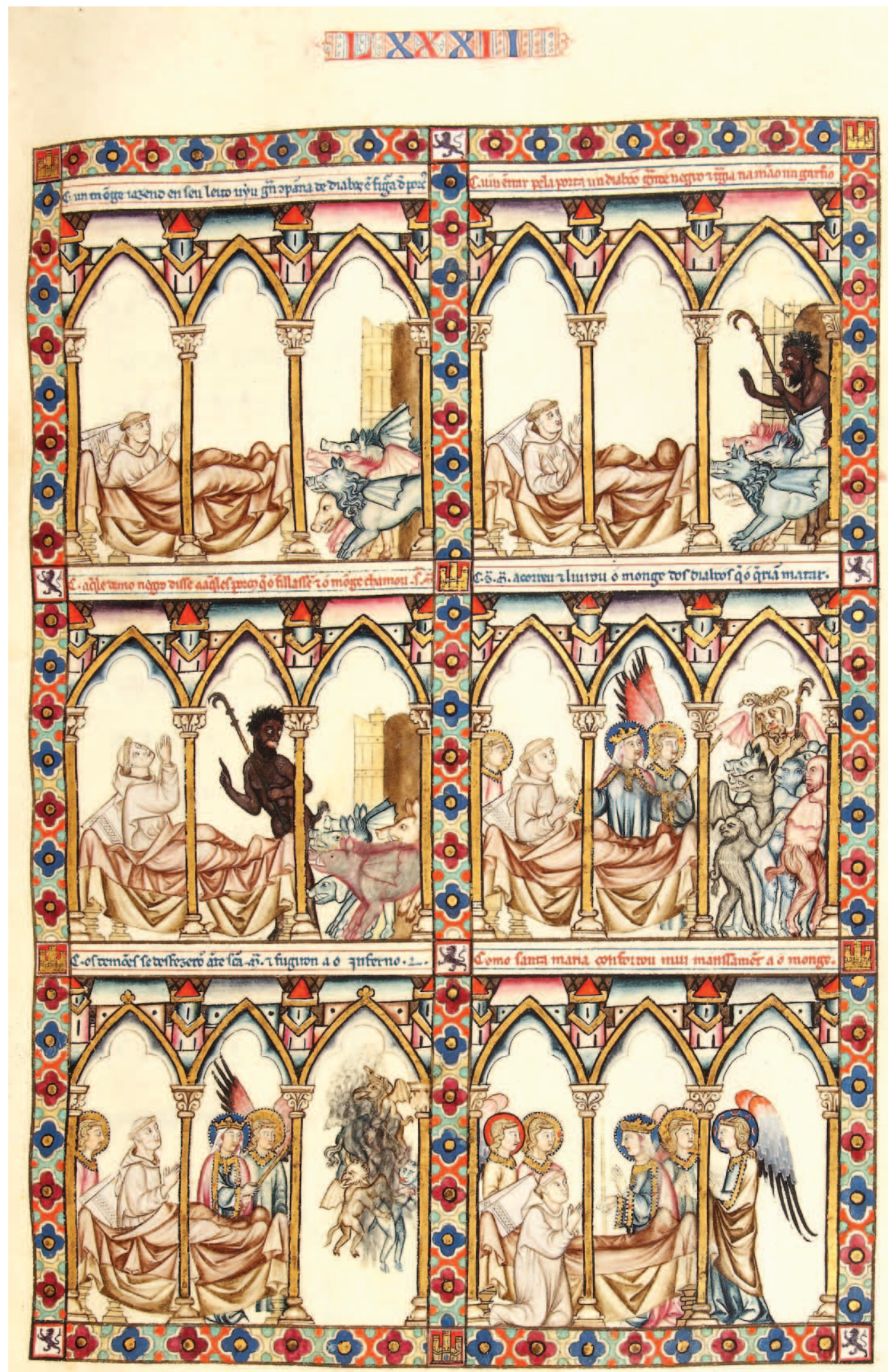

Figure 12. Illustration for Cantiga 82, "How Holy Mary Protected a Monk from Devils Who Wanted to Tempt Him and Appeared in the Form of Swine," fol. 120r, Cantigas de Santa María, ca. 1280, Madrid, Real Biblioteca del Monasterio de San Lorenzo de El Escorial, MS T-I-1 (photo: (C) Patrimonio Nacional). 


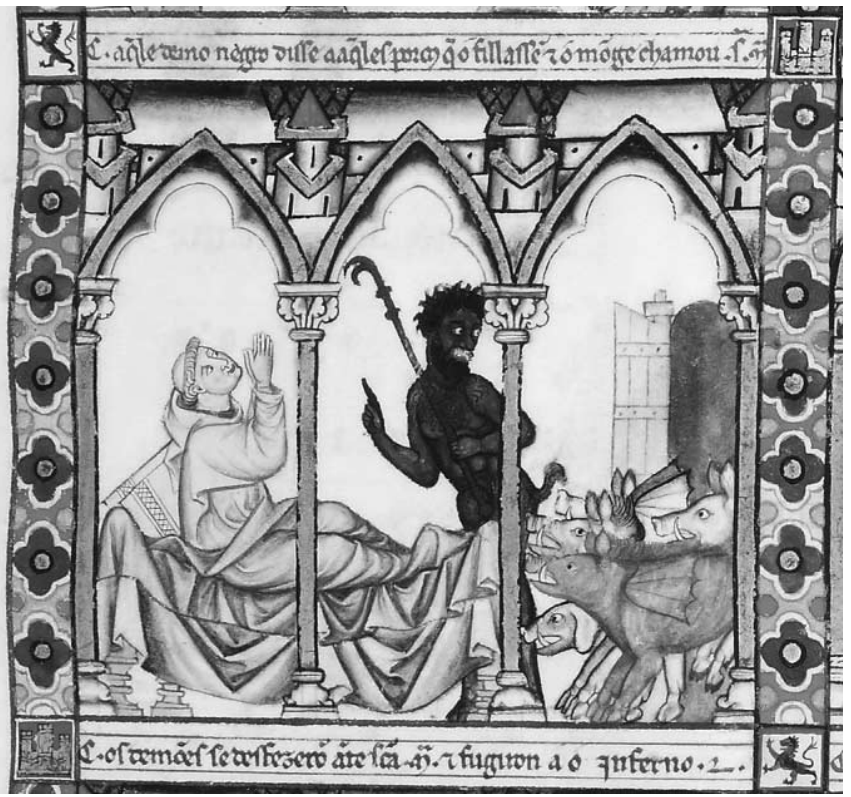

Figure 13. Satan as an Ethiopian, from Cantiga 82, "How Holy Mary Protected a Monk from Devils Who Wanted to Tempt Him and Appeared in the Form of Swine," detail of fol. 120r, Cantigas de Santa María, ca. 1280, Madrid, Real Biblioteca del Monasterio de San Lorenzo de El Escorial, MS T-I-1 (photo: (C Patrimonio Nacional). See the electronic edition of Gesta for a color version of this image.

Cantiga 82 shares the unorthodox streak displayed by the other Iberian examples (Figs. 12-13). Not only does it offer the most literal example in the manuscript of the devil's depiction as an Ethiopian but it does so without clear narrative precedent. Other surviving thirteenth-century manuscripts of this widely circulated tale make no reference to Satan's blackness, describing him simply as "a man of enormous size" (enormis magnitudinis hominem). ${ }^{51}$ It remains unclear whether the in-

51. I found no reference to the devil's color in the following medieval versions of the tale: Peter the Venerable, De miraculis (Jean-Pierre Torrell and Denise Bouthillier, eds. and trans., Livre des merveilles de Dieu [De miraculis] [Paris: Cerf, 1992], 265-68); Vincent of Beauvais, Speculum historiale 8.112 (Michel Tarayre, La Vierge et le miracle: le Speculum historiale de Vincent de Beauvais [Paris: Champion, 1999], 128-31); Jean Gobi, Scala coeli (MarieAnne Polo de Beaulieu, ed., La scala coeli de Jean Gobi [Paris: Éditions du Centre National de la Recherche Scientifique, 1991], 450); the Mariale magnum (BnF, MS lat. 3177, fols. 146r-147r); the British Library Mariale (London, British Library, Add. MS 15273, fols. 83v-84r); and the Miraculorum B. Mariae, libri III (Reims, Bibliothèque Carnegie, MS 1400, fols. 21r-21v). On the manuscript tradition, see Stephen Parkinson and Deirdre Jackson, "Putting the Cantigas in Context: Tracing the Sources of Alfonso X's Cantigas de Santa Maria," Centre for the Study of the Cantigas de Santa Maria of Oxford University, 7 May 2005, http://users.ox.ac.uk/ srp/zoo5 .pdf, 9, 14-15nn21-22. The Speculum historiale is recorded as being terpolation of this element in the text of the cantiga was the first of its kind, or whether it directly inspired the artist to make this adaptation; in either case, it attests to the currency of the Ethiopian topos at Alfonso's court.

The Iberian examples discussed above offer valuable context for the black skin and exaggerated physiognomy of the serpent in Cantiga 320 (Figs. 1-2). They permit the serpent's Ethiopian features to be understood as a widely recognized disguise for the deceptive Satan that is entirely in keeping with a narrative that hinges on the diabolical temptation of the innocent. For a viewer attuned to such visual traditions, the recognition of the Ethiopian disguise qua disguise would have intensified an awareness of both the devil's presence and his potential to deceive his first human victim, Eve, reinforcing the precariousness of her dilemma.

\section{Women, Blackness, and Sex}

Although its connotations of sinfulness, diabolism, and deceptiveness justify the choice of an Ethiopian visage for the satanic serpent of Cantiga 320, the problem of its feminine appearance remains to be resolved. Its gender poses a paradox: whereas Western medieval images of the Ethiopian preponderantly characterize the type as male, here the serpent's striped chaplet and veil-which resemble those of fashionable Castilian ladies throughout the Cantigas de Santa Maríahew to the long-standing tradition of designating the serpent's human head as feminine. ${ }^{52}$ But would this odd visage, with its black skin, wide lips, and enormous eyes, have been understood by its medieval viewers as female? Could it still have been considered "like" Eve? How might this have refined or reframed the connotations of Satan's disguise in Eden? The answers to these questions concern not just gender, but sex.

Sex was foremost in the minds of many of the early monastic writers in whose texts the demonic Ethiopian first emerged, as is hardly surprising in a context where dual commitments to celibacy and solitude made bodily continence a real concern..$^{53}$ Challenging the monastic vow of chastity was a preferred strategy of the demons described by the desert

in King Alfonso's possession in his 1284 testament; see H. Salvador Martínez, Alfonso X, el Sabio: una biografía (Madrid: Polifemo, 2003), 616-22, at 617; and César Domínguez, "Vincent of Beauvais and Alfonso the Learned," Notes and Queries 45, no. 2 (1998): 172-73.

52. This headdress type appears with some frequency in the Cantigas de Santa María; see Gonzalo Menéndez Pidal and Carmen Bernis Madrazo, "Las Cantigas: la vida en el s. XIII según la representación monográfica (II); traje, aderezo y afeites," Cuadernos de la Alhambra 15-17 (1979-81): 89-154, esp. 131-41 (type 3+4a).

53. Byron, Symbolic Blackness, 85-94; Brakke, Demons and the Making of the Monk, 162-75; and Joyce E. Salisbury, "When Sex Stopped Being a Social Disease: Sex and the Desert Fathers and 
fathers in early patristic writings, which effectively recast Classical notions of Ethiopian hypersexuality in terms of anxieties about physical abstinence. In one famous example, found in Athanasius of Alexandria's fourth-century Life of St. Anthony and echoed as far forward as the Legenda aurea, the devil ends a series of failed temptations by offering himself to the saint in the form of a young black boy, eventually admitting defeat in the face of Anthony's steadfast celibacy. ${ }^{54}$

Still more vivid temptation accounts featured demons in the form of Ethiopian women. ${ }^{55}$ In one such tale, a monk caught visiting a bath by Abba Daniel of Scetis appears to the father as if he were surrounded by demons, while one Ethiopian woman embraces him and another teaches him an unspecified but definitely "indecent" act. ${ }^{56}$ Another episode, included in the late fourth- to early fifth-century Apophthegmata patrum (Sayings of the Desert Fathers), which was widely circulated in Latin, Syriac, and Ethiopic, tells how a boy sent by his father to the wilderness to combat his desires of the flesh has a vision of an Ethiopian woman whose stench-a property associated with prostitution in the ancient and early medieval world-alerts him to the sexual dangers she personifies. ${ }^{57}$ In yet another story, from Palladius's early fifth-century Historia Lausiaca, the monk Pachon tells how, in the course of serial temptations, he was accosted by a demon in the form of an Ethiopian woman he remembered from his youth, who sat on his lap; when he struck her on the ear she departed, but his hand retained her fetid smell. ${ }^{58}$ Recurrent in these narratives is an intriguing tension between such figures' perceived repulsiveness and their sexual appeal: although ugly and foul-smelling ("fetida turpus aspectu"), they exert a powerful attraction over their victims, whose resistance is often physical and sometimes violent. ${ }^{59}$

Such dark-skinned temptresses merged familiar stereotypes concerning the sexuality of Ethiopians with similarly venerable conceptions of the female body as both inherently lascivious and dangerously tempting. Women had long been

Mothers," in Medieval Sexuality: A Casebook, ed. April Harper and Caroline Proctor (New York: Routledge, 2008), 47-58.

54. For the text, see Byron, Symbolic Blackness, 86-87; and Brakke, Demons and the Making of the Monk, 28-29.

55. Byron, Symbolic Blackness, 94-102.

56. Brakke, Demons and the Making of the Monk, 167.

57. The relevant passage is in ibid., 168; see also Byron, Symbolic Blackness, 97-98.

58. Brakke, Demons and the Making of the Monk, 173; for the full text, see W. K. Lowther Clarke, ed., The Lausiac History of Palladius (New York: Macmillan, 1918), 101-3.

59. Byron, Symbolic Blackness, 98-100; and Salisbury, "When Sex Stopped Being a Social Disease," 51-52. For an inverse association of good smells with holiness, see Liz James, "Senses and Sensibility in Byzantium," Art History 27, no. 4 (2004): 522-37. perceived by Christian thinkers as more susceptible to fleshly desires than were men, posing a social danger that could only be controlled by the careful safeguards of male authority. This line of thinking coincided in the central Middle Ages with a new emphasis on clerical celibacy, as well as a rise in theological and medical literature that concretized the notion of women's inherent lustfulness. Medical works such as the Salernitan Questions, composed about 1200, argued somewhat self-contradictorily that despite their cooler, moister nature, women experienced stronger sexual desire than men, a desire described by some scholars as impossible to satisfy. ${ }^{60}$

The element of skin color added a new dimension to such claims, as illustrated by a cluster of quodlibets from late thirteenth-century Paris, which compare the bodily properties of black and white women as a didactic exercise. As Peter Biller has shown, these draw several significant conclusions, among them that black women's "hotter" nature allowed them to produce more nutritious milk and give birth more easily; they also claimed that it increased those women's sex drive and the pleasure they offered in bed. ${ }^{61}$ While the assertions about the richness of black women's milk have Aristotelian roots, Biller has argued that those about sexual energy gained traction chiefly among thirteenth-century scholastic thinkers, including Albert the Great. ${ }^{62}$ Indeed, a possible precursor to this idea was articulated a century earlier by Abelard in a letter to Heloise concerning the Bride in the Song of Songs, which explains that black women's flesh is often "all the softer to touch though it is less attractive to look at, and for this reason the pleasure they give is greater." ${ }^{63}$

Black women are hypersexualized in a more ominous way in several medieval French and English romances in which, as Jacqueline de Weever has observed, virtuous lightskinned Saracen princesses who aid the Christian hero and typically undergo conversion are often juxtaposed to inimical Saracen women who are black and physically deformed,

60. John W. Baldwin, "Five Discourses on Desire: Sexuality and Gender in Northern France around 1200," Speculum 66, no. 4 (1991): 797-819, esp. 817-19.

61. Peter Biller, "Black Women in Medieval Scientific Thought," in "La pelle umana: The Human Skin," Micrologus: natura, scienze et società medievali 13 (2005): 477-92, esp. 479-87.

62. Ibid., 487.

63. Quoted in Thomas Hahn, "The Difference the Middle Ages Makes: Color and Race before the Modern World," Journal of Medieval and Early Modern Studies 31, no. 1 (2001): 1-38; see 23-24. On the extension of such thinking into the later medieval and colonial era, see Valentin Groebner, "The Carnal Knowing of a Coloured Body: Sleeping with Arabs and Blacks in the European Imagination, 1300-1550," in The Origins of Racism in the West, ed. Miram EliavFeldon, Benjamin Isaac, and Joseph Ziegler (Cambridge: Cambridge University Press, 2009), 217-31. 


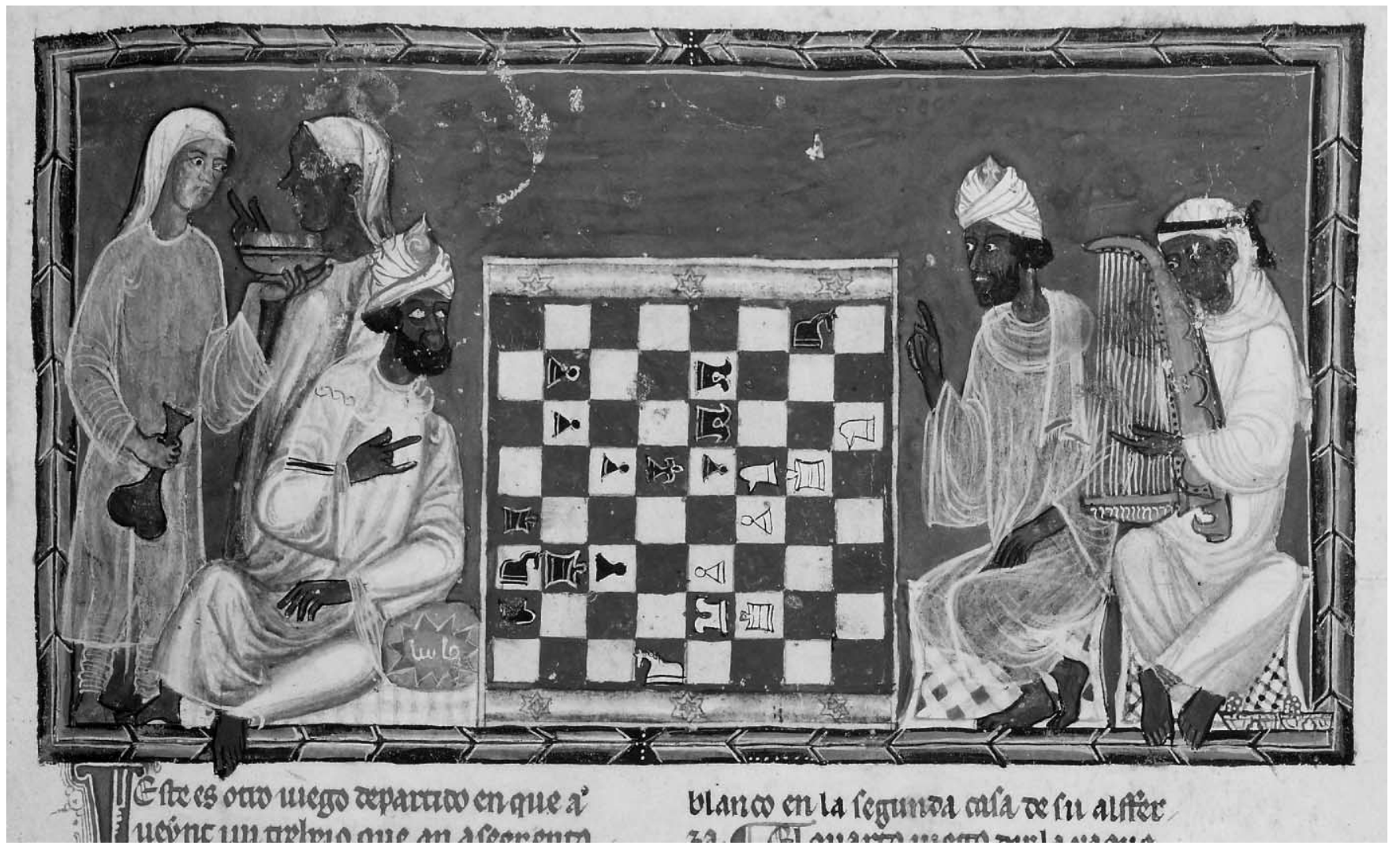

Figure 14. Muslims playing chess, fol. 22r, Libro de ajedrez, dados y tablas, 1283, Madrid, Real Biblioteca del Monasterio de San Lorenzo de El Escorial, MS T-I-6 (photo: (C) Patrimonio Nacional). See the electronic edition of Gesta for a color version of this image.

sexually perverse, and physically dangerous. ${ }^{64}$ One such figure is the Saracen Amiete in Fierabras, a warrior woman "blacker than pepper; long in her crotch, with an enormous mouth" and "taller than an upright lance," with red eyes and wild hair. ${ }^{65}$ Like her literary sisters, Amiete is fiercely destructive on the battlefield, mowing down Frankish soldiers with a long scythe, and both she and they often reproduce monstrously, bearing giant twins, spotted children, or formless lumps of flesh that reconfigure as human only after baptism. ${ }^{66}$

The dual potentialities of pleasure and danger represented by black female bodies in medieval texts are more elusive in medieval imagery. Extremely few images of darkskinned women, tempting or otherwise, appear in western Europe until the very late Middle Ages, as is consistent with

64. Jacqueline de Weever, Sheba's Daughters: Whitening and Demonizing the Saracen Woman in Medieval French Epic (New York: Garland, 1998), 53-109.

65. Ibid., 57.

66. Amiete bears giant twins, whom she abandons to fight; in Parzival, the Saracen queen Belakane, after making her lover Gahmuret king over her country, gives birth to a piebald son. See ibid., 40, 77-78; for additional cases, see Groebner, "Carnal Knowing of a Coloured Body," 219-20. the tendency of medieval artists to confine ethnic and protoracial stereotypes chiefly to male figures. ${ }^{67}$ Whereas in Mediterranean zones, including Iberia, artists occasionally depicted Muslim women with dark hair and skin, such figures tend toward the naturalistic, rarely displaying the exaggeratedly dark skin or stereotyped physiognomy that would have provided a parallel to the textual tradition. In a scene of Muslims playing chess in an illustrated book of games commissioned for Alfonso X in 1283, the Libro de ajedrez, dados $y$ tablas, the two dark-skinned serving women are notably individualized: one has a coffee-colored complexion and youthful European facial features; the other has darker brown skin, red lips, and a bony nasal profile (Fig. 14) ${ }^{68}$ Even the marginal

67. This can be observed, for example, in medieval depictions of Jewish women, which very rarely share the physiognomic deformities so often assigned to Jewish men. Sara Lipton, "Where Are the Gothic Jewish Women? On the Non-Iconography of the Jewess in the Cantigas de Santa Maria," Jewish History 22, nos. 1-2 (2008): 139-77.

68. RBME, MS T-I-6, fol. 22r. Luis Vázquez de Parga identifies the lighter-skinned figure as a mulata and the pair as the only etíopes in the manuscript, overlooking another light-brown-skinned figure with African features, this time male, on fol. 55r. Vázquez de 


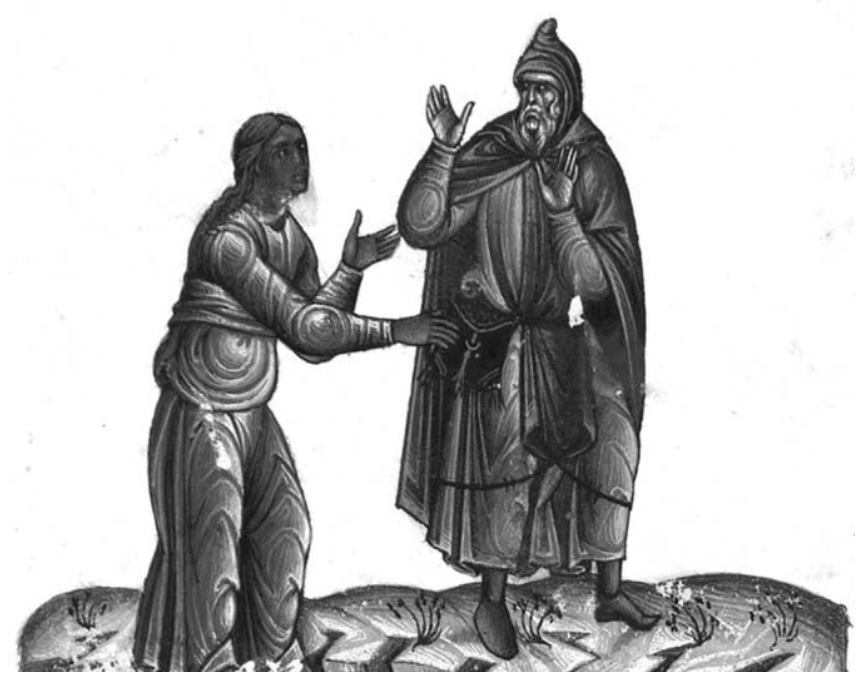

Figure 15. Abbot Arsenius accosted by an Ethiopian woman, detail of fol. 101v, Vitae patrum, fourteenth century, Vatican City, Biblioteca Apostolica Vaticana, MS lat. 375 (photo: (c) 2016 Biblioteca Apostolica Vaticana, by permission of the Biblioteca Apostolica Vaticana, all rights reserved).

illustration of an Ethiopian girl who accosts the wandering desert father Arsenius in a fourteenth-century manuscript of the Vitae patrum from Palermo adopts the normative physiognomy of western Europe and is differentiated only by her darkened skin (Fig. 15). ${ }^{69}$

Medieval images of biblical women who were habitually considered dark-skinned, such as the Queen of Sheba, display a similar restraint. Depictions of the queen, by far the most commonly represented of these, fluctuate unpredictably between pale- and dark-skinned, and her physiognomy consistently conforms to Western ideals. Even the deep black niello of the Queen of Sheba on the late twelfth-century Klosterneuburg altar ensemble is tempered by the queen's typically European features, which stand in contrast to the vaguely

Parga, "Alfonso el Sabio," in the commentary volume of Libros de ajedrez, dados y tablas, 13-28, at 21n22. See also Libro de ajedrez, dados y tablas de Alfonso X el Sabio: estudio, ed. Pilar García Morencos (Madrid: Patrimonio Nacional, 1977). On the images as reflective of court life and ideals, see Olivia Remie Constable, "Chess and Courtly Culture in Medieval Castile: The Libro de ajedrez of Alfonso X, el Sabio," Speculum 82, no. 2 (2007): 301-47.

69. Vatican City, Biblioteca Apostolica Vaticana, MS lat. 375, fol. 101v. For the tale, see Brakke, Demons and the Making of the Monk, 171-72. For the manuscript, see Hugo Buchthal, "Early Fourteenth-Century Illuminations from Palermo," Dumbarton Oaks Papers 20 (1966): 103-18; and Marco Vattasso and Pio Franchi de' Cavalieri, eds., Codices Vaticani latini, vol. 1, Codices 1-678 (Rome: Vaticanis, 1902), 292-93.

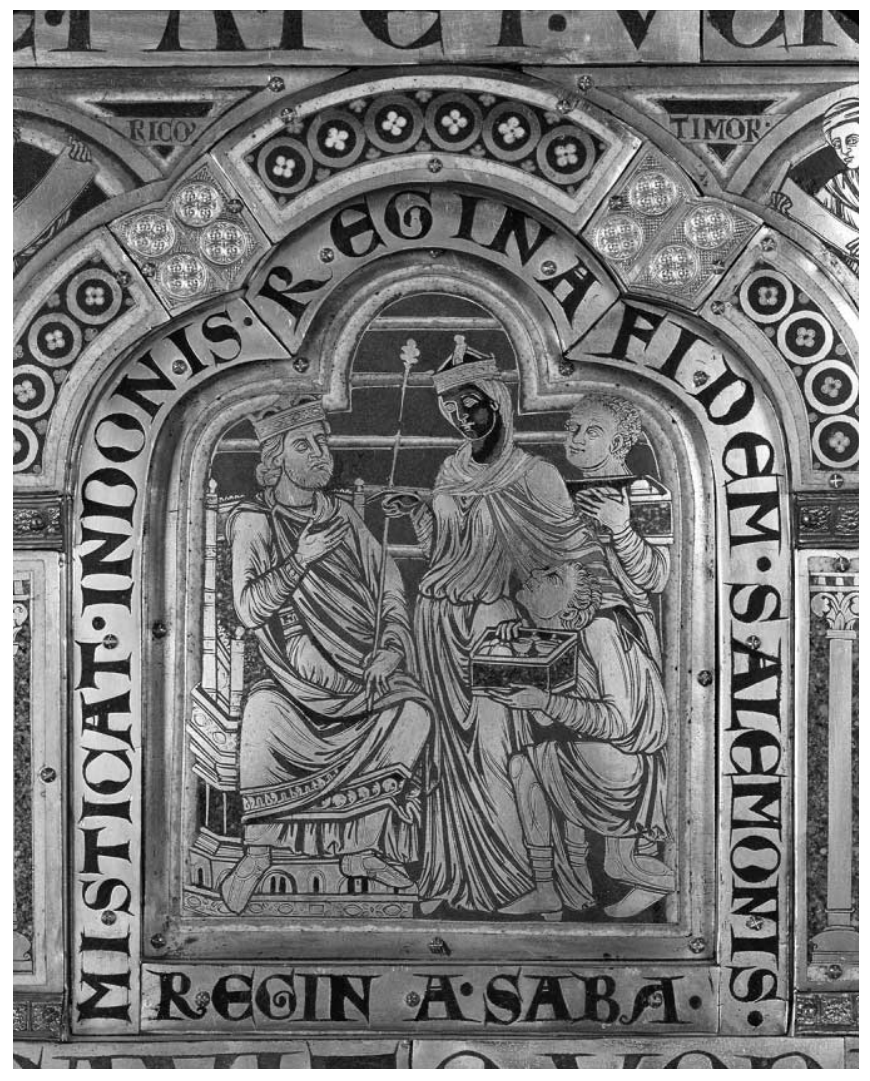

Figure 16. Nicholas of Verdun, Solomon and Sheba, 1181, detail of the Klosterneuburg altar ensemble, Klosterneuburg Abbey (photo: Erich Lessing/Art Resource). See the electronic edition of Gesta for a color version of this image.

Africanized physiognomies of her oddly light-skinned retainers (Fig. 16). As Madeline Caviness has argued, the symbolic freight borne by the queen's dark skin varied according to her context, appearing mainly when her foreign origin or pagan faith was at issue. While dark skin in itself may have permitted what Caviness describes as a mildly pejorative reading, this would have been far gentler than the near-monstrous connotations attached to black women outside the Bible. ${ }^{70}$

Medieval images of King Solomon's foreign wives at times depicted at least one as dark-skinned. According to the biblical narrative (3 Kings 11:1-10), the aged Solomon strayed from God's command by taking wives and concubines from

70. Caviness, "(Ex)changing Colors," esp. 558-64. It is not until the fourteenth and fifteenth centuries that the Queen of Sheba begins to be perceived more negatively as Solomon's temptress; on this, as well as the variability of the queen's skin color, see de Weever, Sheba's Daughters, 83-85. On Sheba in Jewish and Islamic tradition, where she seems to have been understood more negatively, see Jacob Lassner, Demonizing the Queen of Sheba: Boundaries of Gender and Culture in Postbiblical Judaism and Medieval Islam (Chicago: University of Chicago Press, 1993). 
among foreign peoples, becoming so susceptible to their influence that they persuaded him to worship their gods. Although the biblical account does not identify these women as Ethiopian, some later traditions say that one wife was the daughter of Pharaoh, whose Egyptian origins might explain her occasional depiction as black. ${ }^{71}$ In such late medieval images, Solomon is represented worshipping an idol under the guidance of a crowned figure whose courtly Western dress, and occasionally blond hair, is set off by a brown or black complexion, as in the 1411 manuscript of Hans Vintler's Blumen der Tugend in Vienna (Fig. 17). ${ }^{72}$

While such figures are generally idealized enough to share the Queen of Sheba's exotic, pagan connotations, the wives' relationship with the aged king was both more predatory and more explicitly bound up with sexuality. ${ }^{73}$ The Bible itself allows room for this by explaining that when Solomon was old, "his heart was turned away by women to follow strange gods" (3 Kings 11:4). That this redirection involved sexual temptation is implicit in texts like the Speculum humanae salvationis, which places Solomon's lovestruck worship of idols in the context of other patriarchs who were also misled by feminine temptation. It is also suggested in Vintler's fifteenth-century claim that Solomon was pressured into sinful worship by "a black heathen [woman]" who caused him to lose his mind. ${ }^{74}$

71. Shaye J. D. Cohen, "Solomon and the Daughter of Pharaoh: Intermarriage, Conversion, and the Impurity of Women," Journal of the Ancient Near Eastern Society 16-17 (1984-85): 23-37.

72. Vienna, Österreichische Nationalbibliothek, Cod. 13567, fol. $6 r$. The earliest of these date to the second decade of the fifteenth century; see, e.g., the one in a Bohemian Bible of 1417 (Olomouc, State Library, MS M III 2), fol. 14v, illustrated in Suckale-Redlefsen, Mauritius, 25. Jean Devisse and Michel Mollat reproduce several other examples but at times fail to distinguish between images of the foreign wives and those of Sheba; Devisse and Mollat, "The Shield and the Crown," in The Image of the Black in Western Art, vol. 2, pt. 2, From the Early Christian Era to the "Age of Discovery": Africans in the Christian Ordinance of the World, ed. David Bindman and Henry Louis Gates Jr., new ed. (Cambridge, MA: Belknap Press, 2010), 66-70. See also the thoughtful thesis by Unn Segrén, "Idolatress or Idol? The Symbolism of the Black Woman and the Idolatry of Solomon in the Speculum humanae salvationis" (BA thesis, University of Lund, 2013). The Vintler image is sometimes misidentified as the Queen of Sheba leading Solomon to worship idols. It is identified correctly, but discussed only briefly, by Franz-Josef Schweitzer, Tugend und Laster in illustrierten didaktischen Dichtungen des späten Mittelalters: Studien zu Hans Vintlers Blumen der Tugend und zu des Teufels Netz (Hildesheim: Olms-Weidmann, 1993), 198.

73. Caviness, "(Ex)changing Colors," 560.

74. "Man vindt doch in der alten schrift, / do Salomon den tempel stift, / das in zwang ain schwarze haidenin / durch der selben willen verlos er sein sin, / das er gotes verlaugent damit, / wann er pett di abgötter an nach irem sit” (lines 823-28). Quoted in Ignaz V. Zingerle, ed., Die Pluemen der Tugent des Hans Vintler (Innsbruck: Wagner, 1874), 27-28. For the Speculum humanae salvationis, see

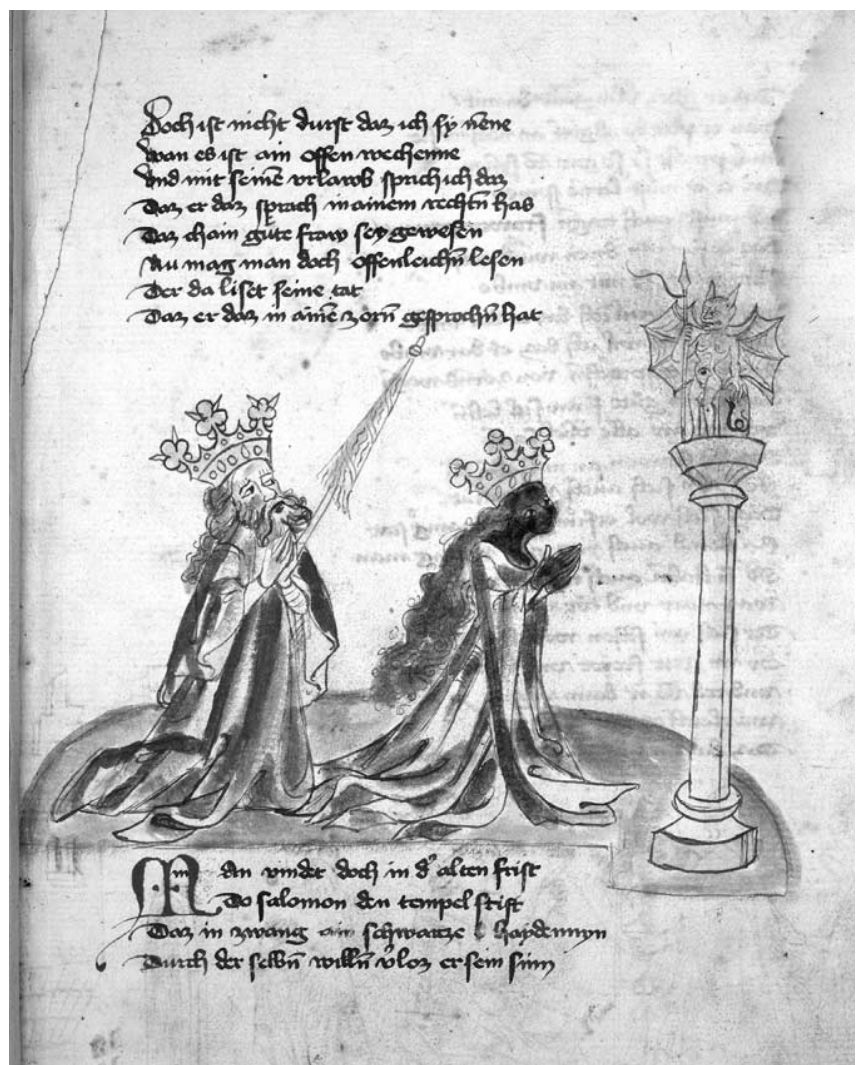

Figure 17. Solomon and his foreign wife worshipping an idol, fol. $6 r$, Hans Vintler, Blumen der Tugend, 1411, Vienna, Österreichische Nationalbibliothek, Cod. 13567 (photo: Österreichische Nationalbibliothek, Vienna). See the electronic edition of Gesta for a color version of this image.

Unlike the "foreign" color of the decorous Queen of Sheba, the dark skin of these temptresses speaks not just to their exoticism but also to their implicitly sexualized power. In the eyes of late medieval thinkers, it might also have linked them with the first temptress, Eve, a connection alluded to in a Flemish manuscript of the Speculum humanae salvationis dated 1430, in which a portrayal of Solomon led to worship by a black wife is juxtaposed to Eve's temptation by the serpent (Fig. 18). ${ }^{75}$

Albert C. Labriola and John W. Smeltz, eds., The Mirror of Salvation = Speculum humanae salvationis: An Edition of British Library Blockbook G.11784 (Pittsburgh: Duquesne University Press, 2002), 18.

75. Copenhagen, Kongelige Bibliotek, MS GKS $792^{\circ}$, fol. 16 r. The juxtaposition is logical in the context of the text's pointed comparison of Adam's temptation by Eve with Solomon's by his wife, but a paired image of this kind is unusual. For the manuscript, see Bert Cardon, Manuscripts of the Speculum Humanae Salvationis in the Southern Netherlands (c. 1410-c. 1470): A Contribution to the Study of the 15th Century Book Illumination and of the Function and Meaning of 


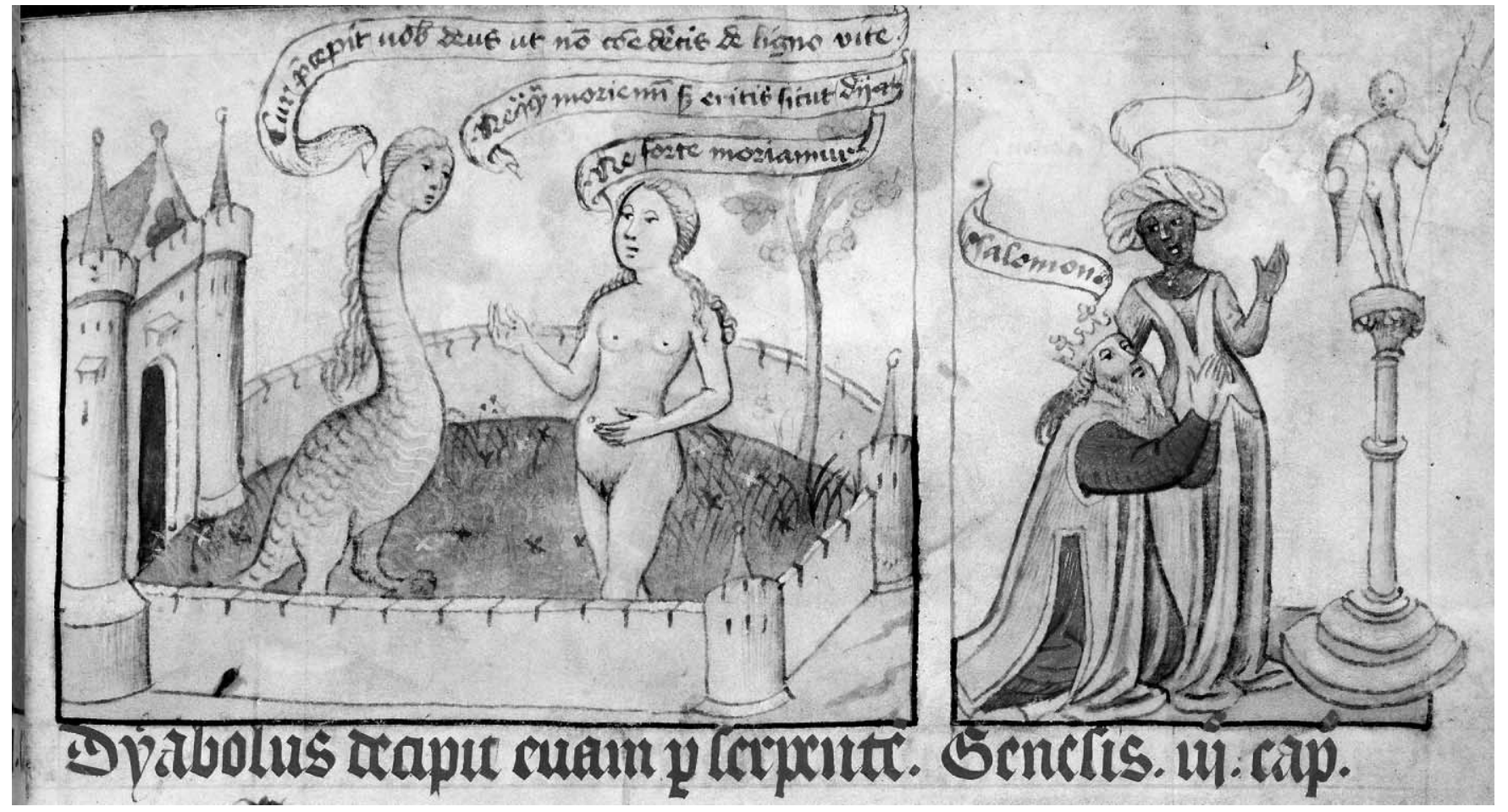

Figure 18. Temptation of Eve and Solomon and his wife worshipping an idol, fol. 16r, Speculum humanae salvationis, 1430, Copenhagen, Kongelige Bibliotek, MS GKS $792^{\circ}$ (photo: Royal Library, Copenhagen). See the electronic edition of Gesta for a color version of this image.

The very opposite of the demure, fair-skinned European ideal, the dark-skinned temptress of the central and late Middle Ages thus blended the generic connotations of foreignness, sin, and danger that were traditionally attributed to Ethiopians with the perilous attractiveness ascribed to the female body. As such, the type lent potent associations to the black, feminine face of the serpent confronting Eve in Cantiga 320 (Figs. 1-2), whose evocation of the sexual appetite and sensual appeal imputed to dark-skinned women would have been intensified by its congruency with the contemporaneous understanding of Eve's role in humanity's Fall. While the Genesis text (3:6) says little that would characterize Eve as a temptress, merely stating that after eating the apple "she gave it to her husband, who ate it" (deditque viro suo, qui comedit), medieval commentators increasingly described Eve's deed as a deliberate seduction of her husband - an act of "wicked persuasion," as Bonaventure put it-and by the late Middle Ages, Eve had become the prototype of deceptive wife and Adam the deluded, victimized husband whom she had beguiled into sin. ${ }^{76}$ Eve's role in the Fall was widely thought of

Historical Symbolism (Leuven: Peeters, 1996), 165-85; 170-71 for the pairing of the Temptation with the scene of Solomon and his wife.

76. Flood, Representations of Eve, esp. 65-80; Flores, “"Effigies amicitiae," esp. 173-90; and Jean M. Higgins, “The Myth of Eve: The as a specifically sexual one: Augustine had described original sin as expressed and conveyed through sexual desire, transmitted down the generations precisely by the lust experienced during the sexual act thought to have resulted from Eve's temptation. ${ }^{77}$

The black-faced serpent's visual inversion of an innocent, prelapsarian Eve would have activated all the connotations of seduction, pleasure, and danger that underlay its narrative. Dark skin faces light; exaggerated features confront idealized ones; dangerous carnality answers spiritual purity in a kind of reversal fundamental to medieval thought, through which the dramatic opposition of contrasting types became a means to understanding both social and soteriological hierarchies. ${ }^{78}$ In this case, the opposition of the sinless first woman and her

Temptress," Journal of the American Academy of Religion 44, no. 4 (1976): 639-47. For a later view of Eve, see Yona Pinson, "Led by Eve: The Large Ship of Female Fools and the Five Senses (1498; 1500)," Word \& Image 26, no. 2 (2010): 214-27.

77. City of God, bk. 14, chaps. 2-10 and 16-23; see Augustine, The City of God against the Pagans, ed. and trans. R. W. Dyson (Cambridge: Cambridge University Press, 1998), 581-603, 614-25. For the legacy of this idea, see Baldwin, "Five Discourses on Desire," 801.

78. On the propensity toward inversion in the central and later Middle Ages, see Michael Camille, Image on the Edge: The Margins of Medieval Art (London: Reaktion Books, 1992), 26-31; and Maria 
sinful interlocutor both forecast and illustrated the dimensions of Eve's eventual crime, observably embodying the sins that would contribute to her fall and revealing, like Dorian Gray's picture, "the hideous corruption" of her soul. ${ }^{79}$

The Edenic serpent of Cantiga 320 would have been understood as "like" Eve, then, not in its superficial appearance but in its moral status, in its prefiguration of the sinless first woman's fall into sin. This inversion is a monstrous one, in the sense suggested by Jeffrey Jerome Cohen in the sixth thesis of his well-known Monster Theory: "Fear of the Monster Is Really a Kind of Desire." 80 The potential of the serpent's black female features simultaneously to attract and repel-to manifest all the forbidden and transgressive behaviors that inexorably ruptured the innocence of Eve's paradise-demarcates the boundary between the innocent perfection of the first parents' life in Eden and the new travails, as well as the new pleasures, that they would encounter after leaving the garden. On a finer scale, the serpent's oppositional features also mark the boundaries between Eve's pure and fallen states, forming a binary that Christian thinkers explored repeatedly, sometimes in literally coloristic terms, as when Prudentius described the sinless Eve as "white as a dove" before being "blackened by venom of the serpent through his deceitful tempting." ${ }^{\prime 1}$ By embodying the moral limit that Eve is destined to cross, the black-faced serpent of the Cantigas de Santa María renders its victim's corruption visible in similarly stripped-down terms rooted in the cantiga text's characterization of Eve as a sinful, ruined figure whose misdeeds could only be undone by a pure, redemptive Virgin.

\section{Color and Gender in Late Medieval Castile}

Recognizing the serpent's multivalent potential permits a return to the question of its significance in its own context. What would a satanic serpent with a female Ethiopian head have meant to the artist who created it and to those late thirteenth-century viewers privileged to view it? Answering this question requires closer scrutiny of the miniature's production within the setting of the royal scriptorium, where the Florence codex apparently had remained, still unbound and

Corti, "Models and Anti-Models in Medieval Culture," New Literary History 10, no. 2 (1979): 339-66, esp. 350-57.

79. Oscar Wilde, The Picture of Dorian Gray (London: Vintage Books, 2007), 108.

80. Jeffrey Jerome Cohen, "Monster Theory: Seven Theses," in Monster Theory: Reading Culture, ed. Jeffrey Jerome Cohen (Minneapolis: University of Minnesota Press, 1996), 16-20.

81. Quoted in Caecilia Davis-Weyer, Early Medieval Art, 3001150: Sources and Documents (Toronto: University of Toronto Press, 1986), 25. See also Verkerk, "Black Servant, Black Demon," 68. awaiting further interventions, after the king's death in 1284 . The book patronage of Alfonso's successor, the rebellious Sancho IV (r. 1284-95), was no match for that of his prolific father: it centered primarily on a handful of historical works. Two of these, however, offer meaningful comparison with the Florence codex: a chronicle of the First Crusade known as $L a$ gran conquista de Ultramar (Madrid, Biblioteca nacional de España, MS 1187) and a continuation of Alfonso's ambitious history of Spain, the Estoria de España (RBME, MS X-I-4). ${ }^{82}$

Abundant empty spaces in both of these manuscripts suggest that an extensive program of illustration was planned for each; however, very few pages were completed under Sancho's patronage. They include the first two battle scenes of La gran conquista de Ultramar (fols. $1 \mathrm{r}$ and $2 \mathrm{r}$ ) and a single portrait of King Ramiro I and his courtiers, now in quite poor condition, in the Estoria de España (fol. 23r). Fernándo Gutiérrez Baños characterized the dry, derivative style of all three miniatures as "post-Alfonsine" because it so evidently relied on traditions established in the learned king's workshop. ${ }^{83}$ They compare profitably with the retrospective stylistic approach of Cantiga 320, which shares with them such characteristic traits as darkly contoured heads with oily S-shaped locks of hair; distinctively drooping eyelids; and, in figures shown in profile, a slightly upturned nose above compressed, slightly protruding lips. ${ }^{84}$ Although clear differences in executionand in the case of the Estoria de España, substantially inferior draftsmanship-suggest they were painted by different artists, these common features support the likelihood that Cantiga 320 was illustrated by an artist working in Sancho's scriptorium.

Much of this scriptorium's energy was devoted to the continuation of manuscript projects that had been begun under Alfonso X, as exemplified by the Estoria de España, undertaken by Alfonso around 1270 but left unfinished at his death.$^{85}$ Progress on this chronicle under Sancho's patronage

82. Fernando Gutiérrez Baños, Las empresas artísticas de Sancho IV el Bravo (Valladolid: Junta de Castilla y León, 1997), 201-32.

83. Ibid., 208; 221-23 on the miniatures' conscious preservation of Alfonsine traditions.

84. For illustrations, ibid., 283-85. High-quality images of the Gran conquista de Ultramar miniatures are available in the Biblioteca Digital Hispánica of the Biblioteca nacional de España (http:// bdh-rd.bne.es/viewer.vm?id=0000045072\&page $=1$ ); for a color image of the Estoria de España miniature, see Rosa M. Rodríguez Porto, "Inscribed/Effaced: The Estoria de Espanna after 1275," Hispanic Research Journal 13, no. 5 (2012): 385-404, fig. 5.

85 . The work was produced in two phases, an early version preserved as RBME, MS Y-I-2, and an "amplified" version today preserved in RBME, MS X-I-4. On the compilation of the Estoria de España, see Diego Catalán, La "Estoria de España" de Alfonso X: creación y evolución (Madrid: Seminario Ramón Menéndez Pidal, 
was substantial, as attested by the 216 folios of text that were later bound together, if still largely without illustrations, with other gatherings produced under Alfonso X and Alfonso XI to form a factitious codex now in the Escorial Library. ${ }^{86}$ If the unfinished Florence codex likewise remained in the scriptorium at this time, the miniatures for Cantiga 320 and the handful of others thought to be contemporaneous with it may reflect a similar, if less successful effort to bring the illustrated volumes of the Cantigas de Santa María to completion.

The unconventionality of the Cantiga 320 illustration can be better understood in this context. Its unknown designer, perhaps charged with continuing the Cantigas de Santa María project but lacking the firm direction and structured system of production that had characterized the Alfonsine atelier, now single-handedly faced the challenge of elaborating the laconic binaries of a loor about Eve and Mary into six full panels of miniatures. Such flexible conditions surely favored the kind of iconographic innovation that might result in an Ethiopianheaded Edenic serpent whose deep-rooted valences of sin and sex drew out the main themes of its text.

Yet deep-rooted though these themes might have been, they also might have seemed current to many late thirteenthcentury Castilians, who could have recognized the trope of the Ethiopian demon from other visual and textual details in the Cantigas de Santa María itself, or from the many other collections of miracle tales, exempla, and hagiographies that circulated throughout Iberia at the turn of the fourteenth century. ${ }^{87}$ They might also have known of the growing body of

Universidad Complutense de Madrid, 1992); idem, De la silva textual al taller historiográfico alfonsí: códices, crónicas, versiones y cuadernos de trabajo (Madrid: Fundación Ramón Menéndez Pidal, 1997); Inés Fernández Ordóñez, Las Estorias de Alfonso el Sabio (Madrid: Istmo, 1992); and eadem, ed., Alfonso X el Sabio y las crónicas de España (Valladolid: Centro para la Edición de los Clásicos Españoles, Universidad de Valladolid, 2000). On the codices and their images, see also Laura Fernández Fernández, “Transmisión del Saber-Transmisión del Poder: la imagen de Alfonso X en la Estoria de España, Ms. Y-I-2, RBME," Anales de Historia del Arte, Volumen Extraordinario (2010): 187-210; and Rodríguez Porto, "Inscribed/ Effaced."

86. RBME, MS X-I-4, fols. 23-199 and 257-320. On the Sanchine imagery in MS X-I-4, see Gutiérrez Baños, Las empresas artísticas de Sancho IV, 215-23; Rodríguez Porto, "Inscribed/Effaced," 399-403; and Fernández Fernández, “Transmisión del Saber," 198-99, 206-10.

87. The Golden Legend might well have been one of these: assembled in Italy about 1260, the tales in this widely popular work had in some cases circulated throughout Europe even before the collection was formed, often through the preaching of the mendicant orders. They were certainly known in Iberia by the end of the thirteenth century, inspiring the first of the vernacular translations that would comprise the late medieval Flos sanctorum tradition. B. Bussell Thompson and John K. Walsh, "Old Spanish Manuscripts of Prose vernacular texts that catalogued women's deceptiveness and dangerousness to men, several of which had originated in the Alfonsine court. ${ }^{88}$ Among these was the Libro de los engaños de las mujeres (Sendebar), a Castilian story collection commissioned in 1253 by the king's brother Fadrique, in which double-crossing wives and shape-shifting she-devils offer ready analogues to the predatory hybrid of the cantiga illustration. ${ }^{89}$ Less obvious, but still significant, are the references to the dangers of women that emerge in the court's historical works. The Estoria de España itself, summarizing the second- or third-century misogynistic text known as the Life of Secundus, sets the framework for these with the fictitious philosopher's response to the emperor Hadrian's query, "What is a woman?": "Confusion of man, insatiable beast, care without end, war that never rests, immeasurable danger to man" (Confondimiento dell homne, bestia que numqua se farta, cuydado que no a fin, guerra que numqua queda, periglo dell homne que no ha en si mesura). ${ }^{90}$ Women who are both dangerous and dark-skinned appear later in the Estoria, when a retelling of the venerable history of El Cid describes an army of "Moorish" female archers with black skin and partly shaved

Lives of the Saints and Their Affiliations, I: Compilation A (the Gran flos sanctorum)," La Corónica 15, no. 1 (1986-87): 17-28. Other sources included the miracle collections of such authors as Gautier de Coincy and Vincent of Beauvais, as disseminated in works by the Iberian authors Gonzalo de Berceo and Fray Gil de Zamora, as well as in the Cantigas de Santa María. On Coincy's reception in Spain, see Teresa Marullo, "Osservazioni sulle Cantigas de Alfonso e sui Miracles de Coincy," Archivum Romanum 18 (1934): 495-539; on Berceo, see Gonzalo de Berceo, Miracles of Our Lady, trans. Richard Terry Mount and Annette Grant Cash (Lexington: University Press of Kentucky, 1997); on Gil de Zamora, see Fidel Fita, "Cincuenta leyendas por Juan Gil de Zamora combinadas con las Cantigas de Alfonso el Sabio," Boletín de la Real Academia de la Historia 7 (1885): 54-144; and idem, "Treinta leyendas por Gil de Zamora," Boletín de la Real Academia de la Historia 13 (1888): 187-225.

88. For negative views of women in a variety of texts from thirteenth- through fifteenth-century Spain, see María Jesús Lacarra, "Algunos datos para la historia de la misoginia en la Edad Media," in Studia in honorem prof. M. de Riquer (Barcelona: Quaderns Crema, 1986), 1:339-61; and Carmen Elena Armijo, "La imagen de la mujer en el Libro de los gatos," in Visiones y crónicas medievales, Actas de las VII jornadas medievales, ed. Aurelio González, Lillian von der Walde, and Concepción Company (Mexico City: Universidad Nacional Autónoma de México, 2002), 305-22.

89. Elena Ivanova, "Who Is Afraid of Demonic Women? Textual Deformity and Magical Transformation in Sendebar," La Corónica 34, no. 1 (2005): 31-49.

90. My translation. Alfonso X, Primera crónica general de España que mandó componer Alfonso el Sabio y se continuaba bajo Sancho IV en 1289, ed. Ramón Menéndez Pidal with Antonio G. Solalinde, Manuel Muñoz Cortés, and José Gómez Pérez (Madrid: Editorial Gredós, 1955), 1:147. 
heads who join the Almoravid army to besiege Valencia. Elena Lourie has argued that this detail, which she traced to Arabic sources, might have some basis in fact; nonetheless, its resonance with the fantasies about black Saracen warrior women in Romance-language epics is unmistakable. ${ }^{91}$

Castilian literary texts of the same era utilize similar somatic types with even less restraint, describing dangerous women marked not just by dark skin but also by deformity, perverse sexuality, and a bad smell. In another Alfonsine text, the satirical Cantigas de escarnho e maldizer, the poet identifies both dark color and foul odor as attributes of an undesirable woman in a song with the memorable refrain, "I do not desire an ugly damsel who farts before my door." Other objectionable features include "poor color," white hair, and coal-like blackness, all traits that position the cantiga's imaginary woman as a caricature inverting the chivalric ideal of the beloved..$^{92}$ Similarly parodic figures appear in other Castilian works, such as the early fourteenth-century Libro de buen amor, in which the archpriest Juan Ruiz provides a highly sexualized description of the black, distorted features of a lecherous serrana, or mountain girl, whom he encounters in the course of his amorous pursuits. ${ }^{93}$

The blackness, sensuality, odor, and above all perilousness of these figures strongly parallel those of the Ethiopian temptresses first described by the desert fathers in their late antique narratives; this is not surprising, given that some of these apophthegmata appear to have reached Iberia by the later Middle Ages. ${ }^{94}$ Two such tales are preserved recogniz-

91. Elena Lourie, "Black Women Warriors in the Muslim Army Besieging Valencia and the Cid's Victory: A Problem of Interpretation," Traditio 55 (2000): 181-209.

92. Benjamin Liu, Medieval Joke Poetry: The Cantigas de Escarnho e de Mal Dizer (Cambridge, MA: Harvard University Press, 2004), 22; 1-16 for background on the Cantigas de escarnho e maldizer more generally. For the full text of the cantiga, see Alfonso X el Sabio, Poesía: cantigas de amigo, de amor y de escarnio y maldecir, ed. Juan Paredes Núñez (Madrid: Biblioteca Nueva, 2010), 128-31. The relevant passages read: "Non quer' eu donzela fea / que [ant'] mi porta pea. / Non quer' eu donzela fea / e negre come carvon. ...”

93. An extensive description of the girl's ungainly appearance includes crude references to her sexual features and repeated references to her blackness; Juan Ruiz, The Book of Good Love, trans. Elizabeth Drayson MacDonald (London: Dent, 1999), 251-55 (stanzas 1006-21).

94. On the reception of the desert fathers tradition in Iberia, see Andrew M. Beresford, "Reformulating Identity in Medieval Castilian Hagiography: Visions, Dreams, and the Ascetic Imperative," Medium Aevum 82, no. 2 (2013): 293-313; and idem, "Sanctity and Prejudice in Medieval Castilian Hagiography: The Legend of St Moses the Ethiopian," in Medieval Hispanic Studies in Memory of Alan Deyermond, ed. Andrew M. Beresford, Louise M. Haywood, and Julian Weiss (Woodbridge: Tamesis, 2013), 11-38. ably in the Libro de exemplos por A.B.C., written by Clemente Sánchez de Vercial in the second decade of the fifteenth century. The first, a version of Palladius's story about the monk Pachon, describes his temptation by a "moça negra" who sits in his lap. In this variant too, he strikes the girl-not with Palladius's single cuff to the ear, but "great blows to her nose and cheeks" (grandes bofetadas en las narices e en las mexillas) - and when she leaves, her stench remains on his hands for two years. ${ }^{95}$ In the second exemplum, a retelling of the account of the young man sent into the wilderness to combat his fleshly desires, the boy prays by a fountain for twenty days before an increasingly bad odor alerts him to the presence of "a very black and very ugly woman, runny-eyed and covered with sores from which the foul smell was coming." ${ }^{\prime 6}$

Although the emergence of these narratives in an early fifteenth-century collection sets them at some remove from our late thirteenth-century artist's activity, their preservation in the later text suggests that the stereotype of the Ethiopian temptress enjoyed earlier circulation in Castile, perhaps carried there in one of the collections of exempla that were imported into Spain by Franciscan and Dominican preachers during the thirteenth and fourteenth centuries. ${ }^{97}$ Since at least one of the tales just discussed, that of the youth tempted while in meditation, is also found in the Legenda aurea, it is probable that at least a few such stories would have been circulating in Castile by the time the Cantiga 320 illustrator conceived the image of the black-faced serpent.

Romances and preaching were not, of course, Castilians' only exposure to ideas about black-skinned peoples; just as influential at the end of the thirteenth century might have been the increased interaction between Castilian Christians of largely European origin and a substantial population of Muslims claiming Arab, North African, and sub-Saharan African roots. Castile itself had seen a distinct growth in its numbers of black- and brown-skinned inhabitants, both men and women, slave and free, as the crown absorbed the population of conquered Islamic lands in the course of the later Reconquest. ${ }^{98}$ The skin color of such individuals, to judge

95. Exemplo 411 (359), Temptacio carnis valde afrigit [sic] dei sanctos; John Esten Keller, ed., Libro de los exenplos por A.B.C. (Madrid: Consejo Superior de Investigaciones Científicas, 1961), 318-19. See also Lacarra, "Algunos datos," 343.

96. "E luego apareció una mugier muy negra e muy fea, lagañossa e toda sarnosa de la qual salía aquel feodor" (my translation). See Exemplo 197 (126) in Keller, Libro de los exenplos, 158-59; and Lacarra, "Algunos datos," 343.

97. María Jesús Lacarra, Cuentos de la Edad Media (Madrid: Castalia, 1986), 30-50.

98. Beyond the North Africans who formed a substantial population, both free and slave, in Iberia since the Muslim conquest of 
from texts, was liable to provoke a range of assumptions about their religion, origin, and social role. In one apparently typical instance documented by Lourie, a black Christian who had been mistakenly sold into slavery struggled to convince his captors of his free status because his dark skin was understood to mark him as a non-Christian and a slave. ${ }^{99}$ In other cases dark skin seems to have been valued as both exotic and aesthetically pleasing, at least when it was a feature of servants and court retainers. ${ }^{100}$ The latter form of appreciation did not preclude the intrusion of more traditional stereotypes, and it often coincided with them. On fol. 22r of the Libro de aje$d r e z$, for example, the artist's intimate attention to the skin tone, hair, and anatomy of the brown-skinned servant woman whose breasts and hips show faintly through a gauzy garment as she clutches an unmistakably phallic wine flask suggests not merely aesthetic admiration but also a sexualization reminiscent of the Ethiopian seductresses recorded in texts (Fig. 14).

In Seville itself, where the illustrated Cantigas de Santa María had been produced and the Florence codex likely embellished, the social upheavals following the city's 1248 conquest had already sensitized its Christian elite to the potential meanings of dark skin. According to the Estoria de España, most of the city's Muslim inhabitants had been expelled after it fell to Ferdinand III; many more probably departed during the Mudéjar rebellions in Castile and Murcia between 1264 and 1266. However, the consistent mention of resident Muslims in Sevillian documentation of the later thirteenth century indicates that a small but stable population persisted and even expanded there. ${ }^{101}$ Whether composed of

the eighth century, darker-skinned sub-Saharan Africans began to arrive as slaves in Iberia in the eleventh century as a consequence of Muslim slave trading. Such individuals often remained in place after Castile expanded into formerly Muslim lands in the central and later Middle Ages. William D. Phillips Jr., Slavery in Medieval and Early Modern Iberia (Philadelphia: University of Pennsylvania Press, 2013), 18-21, 57-59, and the discussion of racial perceptions on 72-75; for Portugal, see François Soyer, "Muslim Slaves and Freedmen in Medieval Portugal," Al-Qantara 28, no. 2 (2007): 489-516. See also Monteira Arías, El enemigo imaginado, 480-82; and José Luis Cortés López, Los orígenes de la esclavitud negra en España (Madrid: Mundo Negro, 1986), esp. 24-26.

99. Elena Lourie, "Anatomy of Ambivalence: Muslims under the Crown of Aragon in the Late Thirteenth Century," in Crusade and Colonisation: Muslims, Christians, and Jews in Medieval Aragon (Aldershot: Variorum, 1990), no. VII, 1-77, at 53.

100. Núria Silleras-Fernández, “Nigra sum sed formosa’: Black Slaves and Exotica in the Court of a Fourteenth-Century Aragonese Queen," Medieval Encounters 13, no. 3 (2007): 546-65.

101. Manuel González Jiménez, Mercedes Borrero Fernández, and Isabel Montes Romero-Camacho, Sevilla en tiempos de Alfonso X (Seville: Ayuntamiento de Sevilla, 1987), 79-88; and Weibke local Muslims who had weathered the city's initial invasion or of immigrant mudéjares from more stably ruled zones, this community included both subordinate freedmen and slaves and likely comprised both light-skinned Andalusians of Arab descent and the darker-skinned sub-Saharan Africans who had long been integral to western Islamic society. ${ }^{102}$ The presence of these recently conquered and at least occasionally dark-skinned subalterns must have lent a new symbolic freight to skin color in the eyes of the now-dominant Christians, especially since the city's new majority was also well aware of the antagonistic Muslims who remained in the unconquered cities of Andalusia and the Marinid strongholds of North Africa. ${ }^{103}$ Whether these populations were actually dark-skinned or merely envisioned as such by a reactive Christian population, this surely strengthened the connection of blackness with social inferiority and external threat.

All these factors had potential to shape both the creation and the reception of the innovative iconography of Cantiga 320 , the multivalency of which both complicated and intensified the symbolic work that it performed (Figs. 1-2). In overlayering the deep-rooted associations of sin and diabolism often linked with dark skin, the similarly long-perceived implications of sensuality and temptation inherent in the female body, and the dangers posed by a lurking enemy that was frequently imagined as dark-skinned, the motif offered a late thirteenth-century Castilian viewer a rich visual commentary not merely on the Genesis narrative but also on the two main binaries staged by the cantiga itself: first, the juxtaposition of Satan's blackness, evil, and sensuality to Eve's whiteness, innocence, and erstwhile purity; and second, the fallen Eve's capitulation to the darkness of sin and sex to the redemption of a faultless and virginal Mary. Presenting these oppositions in bold and familiar terms, the artist could expect a knowing reception in which the Eva/Ave paradigm articulated in the loor was fully activated and understood. Seen in this light, the artist's audacious decision to represent Satan with the head of a black-skinned woman seems ideally calibrated for a Castilian viewer in whose daily experience dark skin and femininity both bore salient and complex meanings.

Deimann, Christen, Juden und Muslime im mittelalterliche Sevilla: religiöse Minderheiten unter muslimischer und christlicher Dominanz (12. bis 14. Jahrhundert) (Münster: LIT, 2012), 243-52.

102. González Jiménez, Borrero Fernández, and RomeroCamacho, Sevilla en tiempos de Alfonso X, 87-88; Deimann, Christen, Juden und Muslime, 244-47; and Phillips, Slavery in Medieval and Early Modern Iberia, 33-34.

103. James F. O'Callaghan, History of Medieval Spain (Ithaca, NY: Cornell University Press, 1975), 375-77, 391-94; on the mudéjar rebellions of 1264, see also Deimann, Christen, Juden und Muslime, 252-59. 
Like any good hybrid, the Ethiopian-headed serpent of Cantiga 320 opens more doors than it closes. Its sophisticated imbrication of sin and sex, of salvation, diabolism, and danger speaks to more than just the creative insight of a single medieval artist or the social particulars of the court setting in which it was apparently produced. More broadly, it forecasts the growing resonance of skin color and race-the lat- ter, perhaps, in only the faintest medieval sense of gens, or "people"104_in the cultural lexicon of a late medieval Iberian world in which such concerns were soon to become inescapably concrete.

104. Bartlett, "Medieval and Modern Concepts," 42-44. 